Maurice A. Deane School of Law at Hofstra University Scholarly Commons at Hofstra Law

Hofstra Law Faculty Scholarship

2009

\title{
Stopping for Death: Re-Framing Our Perspective on the End of Life
}

Ruth C. Stern

J. Herbie DiFonzo

Maurice A. Deane School of Law at Hofstra University

Follow this and additional works at: https://scholarlycommons.law.hofstra.edu/faculty_scholarship

\section{Recommended Citation}

Ruth C. Stern and J. Herbie DiFonzo, Stopping for Death: Re-Framing Our Perspective on the End of Life, 20 U. Fla. J.L. \& Pub. Pol'y 387 (2009)

Available at: https://scholarlycommons.law.hofstra.edu/faculty_scholarship/629

This Article is brought to you for free and open access by Scholarly Commons at Hofstra Law. It has been accepted for inclusion in Hofstra Law Faculty Scholarship by an authorized administrator of Scholarly Commons at Hofstra Law. For more information, please contact lawcls@hofstra.edu. 


\author{
Ruth C. Stern \& J. Herbie DiFonzo*
}

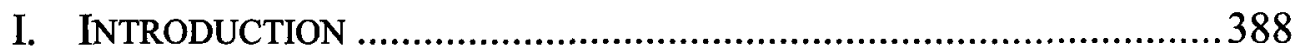

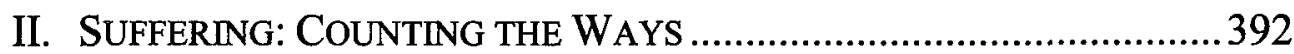

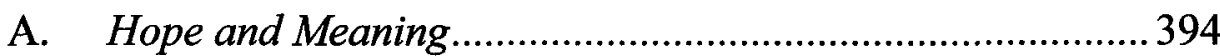

B. Hopelessness and Depression Contrasted ........................... 395

III. DECIDING When ENOUGH IS ENOUGH: GoING

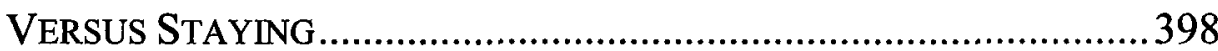

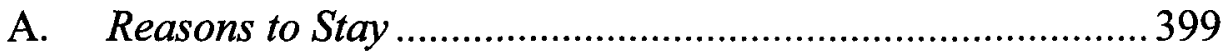

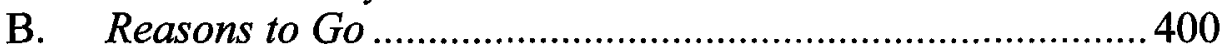

C. The Old and the Existential...............................................404

IV. DOCTOR-PATIENT DISCOURSES ON DYNG ...............................411

A. Speaking of Death ............................................................. 411

B. Doctors and Patients Speaking of Death ............................ 414

V. LAW, MEDICINE, AND THE ART OF DYING .................................417

A. Law in the Service of Limitation ...................................... 417

B. What is the Matter with Oregon?........................................423

C. Promises, Promises: Hospice and Palliative Care .............. 427

D. The Art of Dying..............................................................430

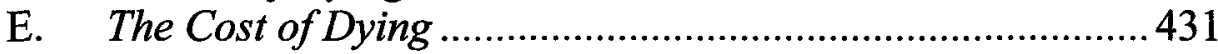

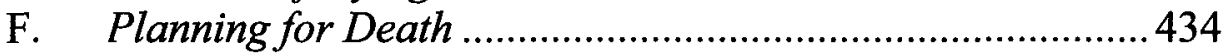

G. Roles and Responsibilities ..................................................435

Because I could not stop for Death, He kindly stopped for me;

The carriage held but just ourselves And Immortality.

Emily Dickinson ${ }^{1}$

* Ruth C. Stern, J.D., M.S.W., attorney at law, branwell226@msn.com; J. Herbie DiFonzo, J.D., Ph.D., Professor of Law, Hofstra University, lawjhd@hofstra.edu. We would like once again to thank Patricia Kasting, law librarian at Hofstra University, for her devotion to craft by locating exactly what we wanted and even material we did not know we needed.

1. Emily Dickinson, Because I Could Not Stop for Death, in THE COLLECTED PoEMS of 
In what direction do the dead fly off the earth?

Rising sun. A thousand blackbirds pronounce day. Jim Harrison ${ }^{2}$

\section{INTRODUCTION}

"What you call dying is simply the last pain-there is really no such thing as dying," wrote Ambrose Bierce. ${ }^{3}$ The character who utters these words, Parker Adderson, is a captured Union spy. Claiming indifference to death's mysteries, he is dismissive of the notion of an interlude between being and nothingness. He jokes about death; he philosophizes. Adderson's manner is peculiarly offensive to the Confederate general who has ordered his execution, a man who finds the very idea of death to be horrible. With the imminence and actuality of his own demise, Adderson's wit and flippancy dissolve into stark, cowering terror. In his fear and panic, he sets off an incident in which the general is gravely wounded. The execution order stands and, as Adderson is dispatched in a hail of bullets, the general finds peace, even beauty, in dying. Adderson's greatest crime, it seems, was not espionage, or even murder, but his failure to give death its due respect.

A reverence for life "requires that we not debase its final stage."4 Our unique philosophies may color both our conduct and experience in dying. To Sherwin Nuland, it is how we live our lives that determines how we die: "Every one of death's diverse appearances is as distinctive as that singular face we each show the world during the days of life." Though the final moments of death are thought to be peaceful, the chore of getting there often exacts a "fearful price." Chronic and terminal illness can command intense anguish - of the mind, body and spiritbefore setting free the sufferer. Some choose to avoid the payment in full, to opt out of the cost of continued existence by hastening their deaths. Sometimes, physicians assist them in obtaining the lethal drugs that will finish the ordeal.

In Washington and Oregon, terminally ill, competent adult residents wishing to die may legally seek medication, to be self-administered, for

EMILY DiCKINSON 712 (Thomas H. Jackson ed., 1890).

2. Jim Harrison, Mother Night, in SAVING DaYlight 55 (2006).

3. Ambrose Bierce, Parker Adderson, Philosopher, in THE CIVIL WAR SHORT STORIES OF AMBrose BIERCE 75, 77 (Ernest J. Hopkins ed., 1988). The ensuing plot summary is drawn from the short story itself.

4. Jack D. McCue, The Naturalness of Dying, 273 J. AM. MED. Ass'N 1039, 1039 (1995).

5. SHER Win B. NulaNd, How We Die: REFLECTIONS ON LifE's Final CHAPTER 3 (1993).

6. See id. at 266. 
the purpose of ending their lives. ${ }^{7}$ The U.S. Supreme Court ${ }^{8}$ and several state courts ${ }^{9}$ have rejected claims for a constitutional right to assisted suicide. In 2009, the Montana Supreme Court, relying on statutory rather than constitutional criteria, concluded that physician aid in dying is not against public policy and that doctors who prescribe lethal drugs, to be self-administered by competent, terminally ill patients, are immune from state prosecution for homicide. ${ }^{10}$ The drive to determine the timing and manner of our deaths, and to seek a doctor's aid in doing so is not, however, a strictly contemporary phenomenon. According to Shai Lavi, the idea of invoking a merciful ending to mortal agony arose prior to the more organized euthanasia movements of the early twentieth century. ${ }^{11}$ First, however, Americans began to transform the course of dying from one of "art" to one of "technique.",

Art, Lavi explained, has the "power to reveal the fullness of a life world," as a Gothic cathedral "make[s] visible" man's relationship to God and the universe. ${ }^{13}$ Dying, when "performed as a work of art," takes the whole of life's essence and enfolds it within the hour of death. $^{14}$ For example, eighteenth and nineteenth century American Methodists engaged in public deathbed spectacles before an audience of friends, family, neighbors, the doctor, and the preacher. ${ }^{15}$ All came to witness the art of dying, a glorious, often boisterous, testament to God's presence, a triumphant holy death that was "life's fulfillment." Technique, by contrast, is not so much "a certain way of doing things" as a belief that a process, even a natural one, can be structured and regulated. ${ }^{17}$ Over time, the doctor replaced the minister as a source of

7. Oregon Death with Dignity Act, OR. REV. STAT. $\S \S 127.800$ (1999); Washington Death with Dignity Act, WASH. REv. CODE $§ 70.245$ (2009).

8. Washington v. Glucksberg, 521 U.S. 702 (1997).

9. See, e.g., Sampson v. Alaska, 31 P.3d 88 (Alaska 2001) (rejecting claim that state manslaughter statute should not be applied to physician who assists patient in committing suicide); Krischer v. McIver, 697 So. 2 d 97 (Fla. 1997) (upholding state statute criminalizing assisted suicide).

10. Baxter v. Montana, 224 P.3d 1211, 1222 (Mont. 2009).

11. Shai LAVI, THE Modern ART Of Dying $41-47$ (2005). The first attempt to legalize euthanasia in America occurred in Ohio in 1906. Id. at 93. The bill was drafted by a layperson who, having witnessed her mother's painful death, lamented that her final agony could not have been eased by the use of chloroform. Id. The bill died in committee. IAN DowBigGn, A MERCIFUL END 18 (2003). The American euthanasia movement of the 1920s and 1930s was tainted by association with the eugenics movement, both proposing to rid society of the deformed, the handicapped and the socially undesirable. See id. at 47-50.

12. LAVI, supra note 11, at 9-13.

13. Id. at 10 .

14. Id.

15. Id at 39 .

16. Id.

17. Id at 10-11. 
hope and comfort at the deathbed. The dying patient's condition was now viewed as one that could be medically managed. As the end of life became increasingly "medicalized," art was subsumed by technique. ${ }^{18}$

Ambrose Bierce's nineteenth century sensibilities were attuned to acute rather than chronic causes of mortality. In his day, one was stricken with pneumonia, influenza, or other infectious diseases and either recovered or died. ${ }^{19}$ Our current, vastly elongated deaths are due to chronic illnesses like heart disease, cancer, and Alzheimer's, as well as to the medical technologies that work to prolong the inevitable. ${ }^{20}$ The drive to hasten death, however, arose long before we developed the means of protracting it. In America, euthanasia was proposed as a solution for a hopeless, painful death as early as $1870 .{ }^{21}$ If medicine could not provide a cure, it could at least "save the patient from dying ... by bringing his life to an end."22 Euthanasia emerged not as a response to an excessively medicalized death, but as a medical remedy for the problem of dying. The story of euthanasia is, essentially, "the tale of how the art of dying gave birth to the technical mastery of dying." 23

The Washington and Oregon statutes, both born of voter initiatives, attest to our continuing preoccupation with controlling how and when we die. Our growing preference for dying at home over "alienating" hospital settings may signal a yearning to re-infuse art into our final moments. ${ }^{24}$ Perhaps, by reviving the "deathbed spectacle," enacting our deaths before loved ones, not strangers, we seek to pay greater homage to the lives we have lived. ${ }^{25}$ At the very least, we have come to believe that dying inhabits its own special sphere of care. If nothing else, our latter-day assisted dying movement has expanded our view of how chronic and terminal illnesses affect the individual. ${ }^{26}$ We are beginning to unknot the tangle of physical, psychological, and spiritual suffering that encumbers the dying and the very ill. We are forced to refine our understanding of pain and how to treat it. We are compelled to examine the crises of hope and meaning underlying what is known as existential distress.

18. Id. at 48-49; Shai Lavi, How Dying Became a 'Life Crisis,' Daedalus, Winter 2008, at 58 [hereinafter Lavi, How Dying Became a Life Crisis].

19. Lavi, How Dying Became a Life Crisis, supra note 18, at 59.

20. Id.; see Ruth C. Stern \& J. Herbie DiFonzo, Terminal Ambiguity: Law, Ethics and Policy in the Assisted Dying Debate, 17 B.U. PUB. INT. L.J. 99, 109-10 (2007) (describing how futile medical procedures can prolong suffering).

21. LAVI, supra note 11 , at 41.

22. Id. at 60.

23. Id. at 12 .

24. Id. at 10 .

25. Id.

26. See generally Stern \& DiFonzo, supra note 20 (analyzing the assisted dying debate). 
For a relative few, despite these better efforts, there is no anodyne but death. The choice to die is neither hasty nor frivolous but often made after valiant attempts to co-exist with pain and suffering. Like it or not, the medical profession is bound up in this enterprise of aid in dying. With no further grounds to justify the "mind-body dichotomy," medicine is being drawn into negotiating the complex universe of individual suffering. ${ }^{27}$ From easing the anguish of chronic illness to comprehending and, perhaps, acceding to a patient's wish to die, it is reasonable and necessary for us to rely on medicine's skills and expertise. The difficulty is that we have come to demand so much more than practical knowledge. In the care of the dying, art may well be the soul of technique.

This Article argues neither for nor against physician aid in dying. Rather, it reflects upon our growing sensitivity to suffering, and how this increased knowledge alters expectations of the doctor-patient relationship. Further, learning more about the nature and impact of serious illness highlights some of the limitations of our current end of life laws and policies. The legal parameters for voluntarily ending our lives are confused and in conflict. Moreover, they have been debated and enacted amidst a cacophony of rights' talk, discourse about the permissible extent of governmental authority and the range of constitutionally-commanded privacy. Indeed, the current clamor threatens to drown out more subtle yet insistent voices asking that, before we bestow a right, we thoroughly investigate the nature of the wrong. But an insufficient amount of scholarly literature has addressed the conditions at ground zero in the assisted suicide debate: the quality of life of those near death, as well as their expectations for care and how a reasonable society might fulfill them.

Following this Introduction, Part II describes the effect of illness and suffering on the individual. Who we are and how we live can influence the nature and extent of our distress and our capacity to cope with it. Suffering is multi-faceted, different aspects of it requiring different types of interventions. Hopelessness and depression, for instance, both associated with suicidal thinking, are different both etiologically and symptomatically. Perceiving their differences is critical to more accurately understanding and empathizing with those suffering intensely. Further, a reconsideration of the mind-body dichotomy requires that we discard the notion of a bright line between physical and psychological suffering. Therapies aimed at treating one or the other ignore the classes of distress resulting from the interplay of both. Part III presents accounts of patients who have chosen to pursue a hastened death. Their reasons for doing so might surprise those who supposed

27. Eric J. Cassell, The Nature of Suffering and the Goals of Medicine 34 (1991). 
that unbearable pain is the most common motivator. A combination of physical suffering, loss of function, and existential issues is often much more paramount than pain, as is the unique personality of the patient.

In Part IV, we discuss ways in which the medical profession confronts (or evades) communications about death and dying. Most doctors are uncomfortable in these discussions, leaving patients feeling bewildered and alone. The fear of future suffering is one of the most dominant forces driving the desire to hasten death. Deserting patients desperately in need of reassurance at this stage belittles their value as individuals, as well as the integrity of medicine. Part V examines our existing legislative and judicial frameworks for analyzing and regulating physician aid in dying. Further, it questions the validity of concepts like "terminal illness" in devising methods to care for the dying, and it illustrates that hospice and palliative care, long believed to be nearly infallible in end of life care, do not benefit all patients. The Article concludes by suggesting that assisted dying is but one of several ways to manage our own dying. What is more important is that, in an era of shrinking health care resources, we may be compelled to revise the ways in which we think about death.

\section{Suffering: Counting THE WAYS}

I look to the time with you to keep me awake and alive. Peter Gabriel $^{28}$

Faith: Belief without evidence in what is told by one who speaks without knowledge, of things without parallel.

Ambrose Bierce ${ }^{29}$

There are several synonyms for suffering: torment, agony, anguish, and misery come to mind. But none of these conveys the sheer kinetic nature of the process, the strenuous, all-consuming work involved. The word "suffering" connotes an active, ongoing experience, one that is connected with events such as illness that assault the identity and "threaten the intactness of person." 30 Suffering, said Eric Cassell, is "an afflicted state of being." 31

28. PeTER GABriel, In Your Eyes, on SO (Geffen Records 1986).

29. Ambrose Bierce, The Devil's Dictionary, in The Collected Writngs of AMBrose BIERCE 187, 294 (1946) [hereinafter THE COLLECTED WRITINGS].

30. CASSELL, supra note 27, at 33.

31. Eric Cassell, When Suffering Patients Seek Death, in Physician-Assisted Dying 76, 76 (Timothy Quill \& Margaret Battin eds., 2004) [hereinafter QuILL \& BATTIN]. 
Though physical distress like pain or shortness of breath may give rise to it, suffering is "distinct from what initiates it." 32 How a set of symptoms influences one's perception of the future is at the heart of suffering. Thus, pain is a source of anguish when the patient regards it as uncontrollable, overwhelming, and never-ending. ${ }^{33}$ A prolonged state of suffering convinces us that we are no longer who we were and creates a fear that we will never be the same again. ${ }^{34}$ Illness alters our relationship with our bodies, causing us to view them as untrustworthy, as sources of betrayal, and sometimes, humiliation. ${ }^{35}$ Suffering is isolating, even shaming, leading us to stifle our complaints in order not to wear out our caregivers. ${ }^{36}$ With increasing loneliness, the sick begin to "exist at a slight remove from common life," to feel estranged and disinformed, as though they will be "stumbling around until death.,"37

Suffering is deeply personal. Balfour Mount, professor of palliative medicine, explained that "[o]ur patients come to us complaining, not of disease, but of their subjective experience of illness." 38 A sense of physical health depends, not on the lack of pain, discomfort, or other somatic symptoms, but on a form of coping that maintains "selfintegrity." 39 Cassell's depiction of suffering as menacing the "intactness of person" One feels "sundered,"41 as though one is "coming apart,"42 "falling to pieces,"43 "breaking,"44 and "broken." S45 Suffering shatters our most basic linkages: "self from self, self from others, self from God." ${ }^{46}$

32. Id.

33. Id.

34. CASsell, supra note 27, at 58; Beverly Rosa Williams, Dying Young, Dying Poor: A Sociological Examination of Existential Suffering Among Low-Socioeconomic Status Patients, 7 J. PAlliative MED. 27, 28 (2004).

35. Cassell, supra note 27, at 47; Michael Stein, The Lonely Patient 160 (2007).

36. STEIN, supra note 35 , at 54 .

37. Id. at 161 . Beverly Rosa Williams described the "social death" of the terminally ill by noting their inequality in social interactions: "[P]atients are no longer addressed as subjects whose social position is intact. Instead, they are treated as objects whose personal boundaries are no longer respected." Williams, supra note 34 , at 35 .

38. Balfour M. Mount, Existential Suffering and the Determinants of Healing, 10 EUR. J. Palliative Care 40, 40 (2003).

39. Id.

40. CASSELL, supra note 27, at 33.

41. Id. at 54 .

42. Helen Black, Soul Pain: The Meaning of Suffering In Later Life 190 (2006).

43. Id.

44. Id.

45. Id.

46. Id. 
When patients experience pain, it is "pain as shaped by their character and biography." hospitals, prior illnesses, medications, joys and miseries, triumphs and failures, all "form the background for illness." 48 Aside from its profound subjectivity, suffering is multi-dimensional, often driving us to doubt the worth of our beliefs, our dreams, and our very existence. This malaise of mind and spirit, known as existential suffering, produces feelings of futility and loss of hope. ${ }^{49}$ Even in the absence of physical distress, existential sufferers may grow weary with the process of living. For the terminally ill who are tired of dying, this draining away of expectations is often the decisive factor leading to pursuit of hastened death.

\section{A. Hope and Meaning}

Discussing hope in the context of dying seems weirdly incongruous. But the definition, measurement, and analysis of hope appear regularly in the literature on terminal illness. Patients and health care providers acknowledge the therapeutic benefits of hope-in strengthening coping abilities amidst serious or life-threatening illness, and improving the quality of life. ${ }^{50}$ Hope is also believed to promote healing as well as better immune system function and health outcomes. ${ }^{51}$ Many patients, having felt themselves blown apart by illness, strive to reintegrate the various fragments of their being. ${ }^{52}$ Hope is, in a sense, the glue that holds them together as they try to reconnect with their former selves.

Unlike wishing, which stems from a state of want or discontent, hope draws from personal meaning and acceptance. ${ }^{53} \mathrm{~A}$ "perspective on reality, a point of view," hope fosters the perception of the glass as half full rather than half empty. ${ }^{54}$ It is "future-oriented and expectant," combining "aspects of longing and believing for something that is not

47. G.K. Kimsma, Euthanasia for Existential Reasons, LAHEY ClNICAL MED. ETHCS J., 2006, available at http://www.lahey.org/NewsPubs/Publications/Ethics/JournalWinter2006/ Journal_Winter2006_Feature.asp.

48. CASSELL, supra note 27, at 38.

49. Gary Rodin et al., Pathways to Distress: The Multiple Determinants of Depression, Hopelessness and the Desire for Hastened Death in Metastatic Cancer Patients, 68 Soc. SCI. \& MED. 562, 563 (2009).

50. William T. Chimich \& Cheryl L. Nekolaichuk, Exploring the Links Between Depression, Integrity and Hope in the Elderly, 49 CANADIAN J. PsYCHIATRY 428, 429 (2004), available at http://wwl.cpa-apc.org:8080/publications/archives/CJP/2004/july/chimich.asp.

51. Id.; see also Mount, supra note 38 , at 41.

52. BLACK, supra note 42 , at 190.

53. Mount, supra note 38 , at 42.

54. Id. 
certain but at least possible." ${ }^{, 55}$ Hope is manifested in a patient's resolve to be present for one more Thanksgiving, or to attend a grandchild's graduation. It can furnish the incentive to bear up under one more day of suffering "if tomorrow might be different." ${ }^{56}$ In short, patients near death require hope in order to sustain the sense that their lives are meaningful enough to justify their continuing existence. ${ }^{57}$

\section{B. Hopelessness and Depression Contrasted}

Studies of morbidly ill patients have helped to clarify the role of hopelessness in existential suffering. Hopelessness has been identified as one of several elements in what Kissane and his colleagues called "demoralization syndrome." 58 Additional criteria include feelings of helplessness and personal failure, loss of coping motivation, social isolation, persistence of symptoms for more than two weeks, and no association with major depression or other psychiatric disorder. ${ }^{59}$ Demoralization and depression are not one and the same, and hopelessness is the principal feature that distinguishes one from the other. ${ }^{60}$ Rodin et al. defined depression as characterized by "persistent and pervasive low mood and the loss of interest in normal activities." Unlike depressed patients, demoralized patients do not seem prone to anhedonia, or loss of pleasure, in the present. ${ }^{62}$ Rather, demoralization is associated with future, or anticipatory, loss of pleasure. ${ }^{63}$ Hopelessness, with its signature "pessimistic cognitive style," accounts for the temporal quality of this distinction.

While loss of hope arises from existential concerns, some suggest depression is more closely linked to the "physical burden" of illness. ${ }^{65}$ Somatic issues, such as pain and other physical symptoms, impose

55. Kyriaki Mystakidou et al., Illness-Related Hopelessness in Advanced Cancer: Influence of Anxiety, Depression, and Preparatory Grief, 23 ARCHIVEs PsYCHIATRIC NuRSING 138,139 (2009).

56. STEN, supra note 35 , at 41 .

57. Harvey Max Chochinov, Dying, Dignity, and New Horizons in Palliative End-of-Life Care, 56 CA. CANCER J. CLIN. 84, 90 (2006).

58. David W. Kissane et al., Demoralization Syndrome-A Relevant Psychiatric Diagnosis for Palliative Care, 17 J. Palliative CaRe 12, 12 (2001).

59. Craig D. Blinderman \& Nathan I. Cherney, Existential Issues Do Not Necessarily Result in Existential Suffering: Lessons from Cancer Patients in Israel, 19 PaLlIATIVE MED. 371, 371 (2005).

60. Id.

61. Rodin et al., supra note 49.

62. Blinderman \& Cherney, supra note 59.

63. Id.

64. William Breitbart et al., Depression, Hopelessness and Desire for Hastened Death in Terminally Ill Patients with Cancer, 284 J. AM. MED. Ass'N 2907, 2910 (2000).

65. Rodin et al., supra note 49 , at 567. 
"psychological stress" and create risk factors for depression. ${ }^{66}$ Rabkin et al. reported that depression is more prevalent in cancer patients than in the general population. ${ }^{67}$ Among oncologists, however, there is no consensus in defining and recognizing depression in cancer sufferers. ${ }^{68}$ Somatic symptoms like "fatigue, anorexia, psychomotor slowing, and insomnia" are common to both cancer and depression. ${ }^{69}$ For the very ill and actively dying who are bedridden, dependent on oxygen or morphine or both, rarely alert or interactive, the "standard criteria for depressive disorders may not apply."

The connection between hopelessness, depression, and desire for hastened death is also subject to dispute. ${ }^{31} \mathrm{~A}$ study by Ganzini et al. found clinical depression in one of four Oregonians seeking physician aid in dying. ${ }^{72}$ In contrast, studies in other states "suggest that depression and psychosocial distress are prominent among patients who endorse an interest in hastened death." 73 Research by Breitbart et al. proposed that both depression and hopelessness significantly increase desire for hastened death. ${ }^{74}$ Some studies concluded that hopelessness and depression are "mutually reinforcing,"75 while others asserted that hopelessness has a higher correlation with suicidal thinking than depression. ${ }^{76}$ That the two conditions are "not synonymous" has been confirmed by Ganzini and her colleagues, who determined that hopelessness, not depression, was responsible for contemplation of assisted suicide among patients with Amyotrophic Lateral Sclerosis (ALS). ${ }^{77}$

The distinction between hopelessness and depression is also important because of its implications for voluntariness under the Washington and Oregon assisted dying statutes. Both statutes forbid the

66. Id.

67. Judith G. Rabkin et al., Depression, Distress and Positive Mood in Late-Stage Cancer: A Longitudinal Study, 18 Psycho-ONCOLOGY 79, 79 (2009).

68. Id. at 80 .

69. Id.

70. Id. at 85 .

71. Rodin et al., supra note 49.

72. Linda Ganzini et al., Prevalence of Depression and Anxiety in Patients Requesting Physicians' Aid in Dying: Cross Sectional Survey, 337 BrIT. MED. J. 1682, 1684 (2008), available at http://www.bmj.com/cgi/content/full/337/oct07_2/a1682 [hereinafter Ganzini et al., Prevalence of Depression].

73. Id. at 1685 . One study, for example, found that $59 \%$ of patients who seriously desired hastened death were depressed. Id.

74. Breitbart et al., supra note 64.

75. Rodin et al., supra note 49 , at 567.

76. Chochinov, supra note 57.

77. Linda Ganzini et al., Attitudes of Patients with Amyotrophic Lateral Sclerosis and Their Care Givers Toward Assisted Suicide, 339 NEW ENG. J. MED. 967, 969-70 (1998) [hereinafter Ganzini et al., Attitudes of Patients]. 
granting of a lethal prescription to patients "suffering from a psychiatric or psychological disorder or depression causing impaired judgment." Hopelessness is a "cognitive style" rather than a form of psychopathology. Whether it impairs judgment in the manner of a mental disorder is not at all certain. Further, because hopelessness and depression appear to operate independently, it seems necessary to "target these issues selectively." 00 Depression may be treated pharmacologically whereas hopelessness is better addressed by "cognitive therapies." 81 These supportive approaches work to alleviate hopelessness by "encouraging life review to help the patient recognize purpose, value and meaning; exploring guilt, remorse, forgiveness and reconciliation; facilitating religious expression; and focusing on meditative practices that promote healing rather than cure., 82

In formulating intelligent policies and medical strategies for serious illness, it is essential that we diversify our understanding of how this condition affects us. Suffering is so varied, and so deeply rooted in whom we are as individuals, that it defies generalization. Our assumption, for example, that unbearable pain is the driving force behind desire for hastened death, is only partially correct. ${ }^{83}$ Somatic symptoms, existential concerns, and depression each respond to different modes of treatment, and all must be addressed as possible motivators for seeking physician aid in dying. ${ }^{84}$

Equating classic notions of suicide with desire for hastened death may also be misleading. ${ }^{85}$ Is craving an end to suffering truly the same as the compulsion to obliterate one's present existence? Under the Oregon and Washington Death with Dignity statutes, actions taken in accordance with those laws are not construed as suicide or assisted suicide. ${ }^{86}$ Our traditional view of suicide evokes images of "tragic self-

78. OR. ReV. STAT. $\S 127.825$ (2007); WASH. REV. CODE $\S 70.245 .060$ (2009). The language of both statutory sections is virtually identical.

79. Breitbart et al., supra note 64 .

80. Id. at 2911.

81. Ganzini et al., Attitudes of Patients, supra note 77, at 972.

82. Chochinov, supra note 57 , at 97.

83. See, e.g., Oregon Department of Human Services, Public Health Division, Year 112008 Summary, available at http://www.oregon.gov/DHS/ph/pas/arindex.shtml. In a survey of 401 patients from 1998 to 2008 who died in accordance with the Death with Dignity Act, only $23.9 \%$ cited inadequate pain control as a major end of life concern.

84. Breitbart et al., supra note 64, at 2911.

85. For rich analyses of suicide and its causes, see generally, A. Alvarez, The SAVAGE GoD: A STUdy OF SuICIDE (1990); KAY REDFIEld JAMison, Night Falls Fast: Understanding Suicide (1999); Thomas Joner, Why People Die By Suicide (2005).

86. OR. REV. STAT. § 127.880 (2007); WASH. REV. CODE $§ 70.245 .180$ (2009). Nor, for that matter, may these actions be considered active euthanasia, mercy killing, or homicide. Id. Most likely, these constructions are prompted more by liability concerns than metaphysics. 
destruction" impelled by mental instability. ${ }^{87}$ But while patients choosing hastened death appear to want relief, the suicidal seek a kind of transcendence. Thomas Joiner notes that, based on anecdotal and case summary evidence, suicidal individuals "view death in a very peculiar way-namely, that death is somehow life-giving." the link between depression and the "embrace of self-extinction," Daphne Merkin suggested that "suicide victims don't realize they won't be coming this way again. If you are depressed enough, it seems to me, you begin to conceive of death as a cradle, rocking you gently back to a fresh life, glistening with newness, unsullied by you."

Accounts of patients who have opted for physician aid in dying, presented in the next section, seem somewhat more pragmatic. Rather than depression, patients in this group are urged on by "a need for selfpreservation," the wish to effect an exit before their identities disintegrate entirely. ${ }^{90}$ Perhaps, in the minds and motivations of the severely ill, there is a qualitative difference between killing oneself and letting go of life.

\section{Deciding When Enough is ENOUgh: GoING VerSUS STAYING}

You know what? I'm not going to get any better. I'm done... I'm tired of this; there's just no reward.

Anonymous Patient ${ }^{91}$

Longevity: Uncommon extension of the fear of death.

Ambrose Bierce ${ }^{92}$

87. Margaret P. Battin \& Timothy E. Quill, The Argument Over Physician-Assisted Dying, in QuILL \& BATTN, supra note 31, at 2.

88. JOINER, supra note 85 , at 86 . Hours before his 2004 disappearance into the frigid water from the Staten Island Ferry, the actor and writer Spalding Gray telephoned his son to tell him he was "on his way home." Id. at 90 . In addition to severe depression, Gray suffered continuing pain and disability from injuries sustained in a car accident several years earlier. Id. at 57-58.

89. Daphne Merkin, A Journey Through Darkness, N.Y. TIMEs MAG., May 10, 2009, at 35.

90. Margaret P. Battin \& Timothy E. Quill, The Argument Over Physician-Assisted Dying, in QuILL \& BATTIN, supra note 31, at 2.

91. Helene Starks et al., Why Now? Timing and Circumstances of Hastened Deaths, $30 \mathrm{~J}$. PAIN \& SYMPTOM MGMT. 220 (2005).

92. Bierce, The Devil's Dictionary, in THE COLlected Writings, supra note 29, at 237. 


\section{A. Reasons to Stay}

Depression and hopelessness are not integral to terminal illness, nor are they inevitable outcomes of the dying process. The majority of patients in late-stage disease maintain a positive mood and the capacity to take pleasure in their lives even in the final weeks before death. ${ }^{93}$ Existential issues do not necessarily give rise to existential distress. ${ }^{94}$ In a study of culturally and religiously diverse advanced cancer patients in Israel, Blinderman and Cherney encountered instances of lost autonomy, issues of body image (e.g. mastectomy, alopecia), guilt, remorse, and loss of hope and meaning. ${ }^{95}$ But their most salient finding was the relatively low incidence of existential suffering, "despite the prevalence of existential concerns." ${ }^{.96}$ For the most part, these patients had come to terms with past disappointments and current limitations and had adapted to changing health circumstances. ${ }^{97}$ Death and dying were sources of preoccupation for only about half of them. ${ }^{98}$ Existential troubles, the study concluded, could be alleviated by "a strong framework of palliative measures, good family support, effective coping strategies and religious belief systems." $" 99$

The role of religion and spirituality in mitigating existential distress is, by now, well-recognized. In the very ill, spiritual belief has been associated with lower anxiety, increased hopefulness, and better quality of life. ${ }^{100}$ One need not have faith in the afterlife or even a specific deity to achieve spiritual well-being. Creative pursuits, meditation, and contact with nature are comparable ways to satisfy the yearning for spiritual purpose and meaning. ${ }^{101}$ Hospice chaplains, mainly nonsectarian and, therefore, more flexible in their approach to spiritual counseling, are increasingly in demand. ${ }^{102}$ Their job, "to make dying easier," often involves discussions about "regrets, loneliness, conflicts unresolved with relatives living and dead; about dogs, movies and people they loved, the meaning of dreams, the TV show 'Dancing With

93. Breitbart et al., supra note 64, at 2911; Cochinov, supra note 57, at 96; Rabkin et al., supra note 67 , at 83,85 .

94. Blinderman \& Cherney, supra note 59, at 379.

95. Id. at 373-76.

96. Id. at 379 .

97. Id.

98. Id.

99. Id.

100. Chochinov, supra note 57, at 87-88; Rabkin et al., supra note 67, at 83.

101. Blinderman \& Cherney, supra note 59, at 376; Chochinov, supra note 57, at 88 .

102. Paul Vitello, Hospice Chaplains Take Up Bedside Counseling, N.Y. TiMES, Oct. 28, 2008, available at http://www.nytimes.com/2008/10/29/nyregion/29hospice.html?scp=1\&sq= hospice $\% 20$ chaplains $\% 20$ take $\% 20$ up $\% 20$ bedside $\% 20$ counseling\&st=cse. 
the Stars." 103 The Reverend Kei Okada, visiting a patient in the grip of terminal cancer and hopelessness, described the patient's hardest task as "letting go of this cerebral concept of meaninglessness, of nothingness." 104

Extreme reliance on religious coping, however, can have less desirable consequences. A study by Phelps et al. reports a greater preference for aggressive therapies, ventilation, and resuscitation among religious copers, even in cases of medical futility. ${ }^{105}$ Religious copers are less likely to appreciate or understand the meaning of do-notresuscitate orders, and are likely to regard them as "morally wrong."106 The hope for a miracle through God's healing can create "unrealistically optimistic expectations of survival.".107 Or, as in the case of the Israeli patients discussed above, spirituality can be a balm to fear and loneliness. ${ }^{108}$

\section{B. Reasons to Go}

The subjectivity of suffering may generate less than predictable responses to illness, but it also inspires admirable displays of resilience and fortitude. Shows of uncommon strength are not exclusive to stories of survival. They are also seen in patients who ultimately elect to hasten their deaths.

There are times when even the most accommodating sufferers can endure no more pain, no further losses of function, and no additional insults to their bodily and personal integrity. Despite receiving good palliative care, and regardless of prognosis, these patients arrive at a point where they are "ready to end the struggle with their illness." 109 In some cases, the decision to procure life-ending medications is made well before the final act. Anticipatory fear and negative expectations of the future can matter more than one's current state of suffering. ${ }^{10}$ Indeed, several clinicians in Oregon "have expressed surprise at the paucity of suffering at the time of the request [for lethal medications] among these patients." 111 Severe, uncontrolled pain is one of the most

103. Id.

104. Id.

105. Andrea Phelps et al., Religious Coping and Use of Intensive Life-Prolonging Care Near Death in Patients with Advanced Cancer, 301 J. AM. MED. Ass'N 1140, 1145 (2009).

106. Id.

107. Id. at 1146 .

108. Blinderman \& Cherney, supra note 59, at 379.

109. Starks et al., supra note 91 , at 219.

110. Ganzini et al., Attitudes of Patients, supra note 77, at 971.

111. Ganzini et al., Why Oregon Patients Request Assisted Death: Family Members' Views, 23 J. GEn. INTERNAL MED. 154, 156 (2007) [hereinafter Ganzini et al., Why Oregon Patients Request Assisted Death]. 
feared aspects of cancer and a major impetus for contemplating aid in dying. ${ }^{112}$ It is not at all unusual for patients to "dread dying more than they fear death."113 Even some of Blinderman and Cherney's fairly serene patient group worried about the ordeal of dying, "but not about death itself.'

Patients who are troubled by prospective suffering and incapacitation derive a sense of comfort in knowing that, if need be, they possess the means to peacefully end their lives. A study of Oregon patients seeking aid in dying found that those who had received prescriptions for lethal drugs actually had "a lower desire to die and a trend toward lower hopelessness scores." Writing about her father who shot himself in the later stages of cancer, Marcia Angell asserted that, had he had the option of future assistance in dying, he might have chosen to live longer. ${ }^{116}$ Another patient, diagnosed with metastatic ovarian cancer, felt relieved and strengthened by having procured the means to hasten her death: "I felt I had more energy . . . to live in the present time. It just took a big weight off my shoulders somehow, knowing at least that that was one thing that maybe I didn't have to worry about."117 Three years went by before this patient made use of her prescribed lethal medication. ${ }^{1 / 8}$

Implicit in the urge to avoid future suffering is the desire to exert control, to manage the dying process by choosing the time and location of one's death. ${ }^{119}$ During the course of illness, patients learn to distinguish between acceptable and unacceptable losses, and to plumb the delicate balance between "not letting go too soon and not hanging on too long." 120 A common concern among AIDS patients is the need to preserve some vestige of the self, to halt the body's deterioration and "minimize the damage." 121 Akin to the desire for control is dread of losing one's independence. For many patients who pursue a hastened death, the fear or sense of becoming a burden is "almost universal."122

Though patients do adapt to them, functional losses can mount up and, finally, become unendurable. For a formerly fastidious dying

112. Rodin et al., supra note 49 , at 564.

113. Marcia Angell, The Quality of Mercy, in QUILL \& BATTIN, supra note 31, at 22.

114. Blinderman \& Cherney, supra note 59, at 378.

115. Ganzini et al., Prevalence of Depression, supra note 72.

116. Angell, The Quality of Mercy, in QuiLl \& BATTIN, supra note 31, at 21.

117. Robert A. Pearlman et al., Motivations for Physician-Assisted Suicide, 20 J. GEN. INTERNAL MED. 234, 237 (2005).

118. Id.

119. See Starks et al., supra note 91, at 216, 218-19; see also Ganzini et al., Why Oregon Patients Request Assisted Death, supra note 111, at 155.

120. Starks et al., supra note 91, at 216.

121. Pearlman et al., supra note 117 , at 238.

122. Chochinov, supra note 57, at 91. 
woman, the onset of incontinence turned her quality of life "appalling." 123 For another terminally ill patient, whose daily drink of Gatorade was his only remaining pleasure, the final, insupportable loss occurred when he could no longer orally take in fluids. ${ }^{124}$ Inability to engage in the work and activities that define us as individuals erodes our identities and sense of purpose. The feeling of having been evicted from a rightful place in one's own life leaves little cause for staying on.

Helene Starks and her colleagues conducted a series of revealing interviews with the families of thirty-five Washington and Oregon patients who hastened their deaths. ${ }^{125}$ All of the patients were white and had been medically insured, with a mean age of sixty-eight and with a majority having received palliative care either through hospice or home care. ${ }^{126}$ Two-thirds of the patients had viewed religion or spirituality as important and felt that their wish to die was not inconsistent with their spiritual or religious beliefs. ${ }^{127}$ On average, the patients had been living with their illness for 2.5 years and had been actively engaged in planning their deaths for 3 months. ${ }^{128}$

The timing of these patients' deaths said as much about their criteria for weighing the "benefits and burdens of living versus dying" 129 as it did about their medical conditions. Physical and existential events may occur at critical points in chronic or terminal illness and trigger the desire to die. ${ }^{130}$ Among the patients studied, those with prognoses of hours to seven days had worked heroically to keep on living, perhaps because of reasons to remain alive until the chosen time. ${ }^{131}$ Their sustaining a final loss (e.g., the onset of constant vomiting, continuous diarrhea, uncontrollable rectal bleeding) convinced them that death had become unavoidable. ${ }^{132}$ Their choice to short-circuit the dying process was their way of ensuring a peaceful death. ${ }^{133}$ For patients with prognoses of one to four weeks, death was not imminent but certainly "a matter of time." 134 Having experienced multiple losses and exhausted

123. Pearlman et al., supra note 117 , at 236 .

124. Id. at 236-37.

125. Starks et al., supra note 91 , at 215 . Those who had agreed to participate in the study were contacted through physician-assisted suicide advocacy groups like Compassion in Dying, the Hemlock Society, and hospice agencies. Id. at 216. At the time of the study, physician aid in dying had not yet been legalized in Washington.

126. Id. at 218.

127. Id.

128. Id. at 218-19.

129. Pearlman et al., supra note 117 , at 238.

130. Id.

131. Starks et al., supra note 91 , at 220-21.

132. Id. at 220 .

133. Id.

134. Id. at 221-22. 
their treatment options, these patients were "simply waiting it out."135 Explaining his mother's decision to hasten her death at that time, one man said, "So what it gets to is [that] the good days aren't worth what the bad days cost you." 136

Patients with one to six months of life remaining had already endured significant functional losses and anticipated even greater ones. ${ }^{137}$ Not only did they foresee a looming threat to their quality of life, they feared losing the ability to hasten their own deaths. ${ }^{138}$ One man with multiple sclerosis (MS), a disease with an "uncertain timeline," wanted to ingest the lethal medications before he lost his ability to swallow. ${ }^{139}$

Patients with prognoses of more than six months had chronic illnesses that became terminal only if they stopped palliative therapy and allowed the disease to proceed on its own. ${ }^{140}$ One woman, in constant pain from a congenital malformation of the spine, felt as though she was in "an invisible prison," and that it was getting worse. ${ }^{141}$ Another patient had chronic lung disease treated by steroids that so impaired her immune system she was constantly plagued by infections. ${ }^{142} \mathrm{~A}$ third patient suffered from progressive paraplegia and profound itching caused by an autoimmune disease. ${ }^{143}$ Her favorite activities, cooking and painting, were now off-limits to her, and she could face neither the continued pain and disability nor the side-effects of her medications. ${ }^{144}$

Although in general even severe pain can be controlled by medication, some patients reject the physical and mental limitations imposed by heavy use of such drugs. In particular, they are concerned about the "unacceptable, mind-altering effects of pain medications." 145 The first person to ingest lethal drugs under Washington's assisted dying law was sixty-six year-old Linda Fleming, "actively dying" of

135. Id. at 222 .

136. Id.

137. Id.

138. Id.

139. Id.

140. Id.

141. Id.

142. Id.

143. Id. at 223 .

144. Id.

145. Pearlman et al., supra note 117, at 236. See also Colin Fernandes, Coming to Know the Limits of Healing, N.Y. TIMES, Sept. 18, 2009 (discussing other side-effects of opioids. These may include "chronic constipation, sedation and somnolence, a worsening of mood, opioid-induced hyperalgesia (a paradoxical phenomenon in which pain medications actually increase pain), hypogonadism (impaired endocrine function) and addiction. Recent studies also suggest an adverse effect on immune function.”). 
pancreatic cancer. ${ }^{146}$ In a statement released by the aid in dying advocacy group, Compassion \& Choices, Ms. Fleming explained, "I am a very spiritual person, and it was very important to me to be conscious, clear-minded and alert at the time of my death. The powerful pain medications were making it difficult to maintain the state of mind I wanted to have at my death." 147

The resolve to exercise some mastery over the dying process is the common thread that runs through these accounts. Some patients will delay ingesting lethal drugs to celebrate holidays or special family occasions. ${ }^{148}$ Some will arrange an event at which to say their last goodbyes. ${ }^{149}$ Others seem to slip their bonds more quietly, even furtively, as though they were being called away.

\section{The Old and the Existential}

The very old often die from what we term 'natural causes.' Death occurs in the absence of acute or chronic illness, or of any "fatal condition that could reasonably explain" their steep decline. ${ }^{150}$ An eighty-seven year-old woman, "paralyzed, incontinent and unable to speak," with a catalogue of non-fatal ailments and miseries may yet be viewed as not "dying of anything." 151 Still, like many in her condition, she may simply lose interest in eating and drinking, and, over a period of days or weeks, pass away. ${ }^{152}$ It is interesting to note that, in persons of advanced age, weight is a highly "consistent independent predictor of longevity." 153

146. William Yardley, In Washington, First Death Using Assisted Suicide Law, N.Y. TIMES, May 23, 2009, at A10.

147. Id. Compassion \& Choices is a national non-profit organization that advocates for legalization of physician assisted dying and offers guidance on end of life options. Compassion \& Choices, http://www.compassionandchoices.org/learn (last visited Dec. 18, 2009). The organization refers terminally ill, mentally competent patients to hospice, social services agencies and specialists in management of pain and existential suffering. Id. When "that isn't enough," counselors "inform clients how to acquire the means to control the circumstances and timing of their own deaths." Jane Gross, End-of-Life Choices: A View From the Front Lines, N.Y. TIMES, Dec. 11, 2008, at http://newoldage.blogs.nytimes.com/2008/12/11/end-of-lifechoices-a-view-from-the-front-lines/?scp=1\&sq=jane $\% 20$ gross $\% 20$ end $\% 20$ of $\% 20$ life $\% 20$ choic es $\% 20 \mathrm{a} \% 20$ view $\% 20$ from $\% 20$ the $\% 20$ front $\% 20$ lines $\& s t=$ cse.

148. Starks et al., supra note 91 , at 223.

149. Id.

150. McCue, supra note 4, at 1040.

151. Jane Gross, What an End-of-Life Adviser Could Have Told Me, N.Y. TIMES, Dec. 15, 2008, available at $\mathrm{http}: / /$ newoldage.blogs.nytimes.com/2008/12/15/what-an-end-of-life-advisorcould-have-told-me.

152. McCue, supra note 4, at 1040; Gross, supra note 151.

153. McCue, supra note 4 , at 1040. 
The act of foregoing food and fluids in the elderly may be due to degenerative neurological disorders or aging of the brain. ${ }^{154}$ Or the cause may be rooted in major depression, believed to afflict up to thirty percent of people aged sixty-five and older. ${ }^{155}$ Another possibility is that elderly people with no identifiable disease or injury, who no longer wish to eat, drink, or care for themselves, have suffered "the loss of a will to live." 156 Clinical depression is especially common among elderly, long-term residents of institutions like hospitals and nursing homes. ${ }^{157}$ The diagnosis is complicated, however, by the fact that elderly persons may be saddened by the "many real personal and social losses" "158 they have sustained. Sorrow and loss of interest in living may also signal "preparation for dying" 159 rather than a mental disorder.

The right to refuse food and fluids is recognized by most state statutes. ${ }^{160}$ Some patients may experience a degree of pain and suffering in the process, which can be ameliorated by appropriate palliative care. ${ }^{161}$ In Oregon, where physician-assisted dying is legal, almost twice the number of hospice patients hastened death by voluntarily stopping food and fluids than by assisted suicide. ${ }^{162}$ Patients who chose to stop eating and drinking were, on average, older than the assisted suicide patients, less likely to have cancer, and more likely to have a terminal neurological disease such as ALS, which might have prevented them from ingesting lethal medications on their own. ${ }^{163}$ Unbearable physical suffering did not appear to be an important reason for refusing food and fluids, and the desire to control the circumstances of death seemed somewhat greater in assisted suicide patients. ${ }^{164}$ Preferring one means over the other was thought to "depend on the importance placed on control, access to a physician who will prescribe lethal medication, other beliefs, and family views." 165 For those who stopped eating and drinking, death usually occurred within fifteen days, these last weeks of

154. Id.

155. Chimich \& Nekolaichuk, supra note 50.

156. McCue, supra note 4, at 1039.

157. Chimich \& Nekolaichuk, supra note 50; McCue, supra note 4, at 1040.

158. McCue, supra note 4, at 1040.

159. Rabkin et al., supra note 67 , at 85 .

160. Bernard Gert et al., An Alternative to Physician-Assisted Suicide, in PHYsiclan AssisTed SuICIDE: EXPANDING THE DEBATE 194 (Margaret P. Battin et al. eds., 1998).

161. Id. at 190.

162. Linda Ganzini et al., Nurses' Experiences with Hospice Patients Who Refuse Food and Fluids to Hasten Death, 349 NEw ENG. J. MED. 359, 363 (2003), available at http://content. nejm.org/cgi/content/full/349/4/359.

163. Id. at 364 .

164. Id. at 363-64.

165. Id. at 364 . 
life generally rated by nurses as "peaceful, with low levels of pain and suffering." 166

Most patients who voluntarily forego food and fluids believe they are ready to die, that continued existence is pointless, and that their quality of life is poor. ${ }^{167}$ The spiritual and psychological side of a dwindling interest in life recalls the role of existential suffering in the desire to hasten death. Suffering, in and of itself, is highly idiosyncratic. When it stems from largely existential issues, it is even more subjective and, as a basis to pursue aid in dying, even more controversial.

In July 2008, German citizens and lawmakers expressed outrage at the death of seventy-nine year-old Bettina Schardt. ${ }^{169}$ A retired X-ray technician who lived alone, and who had no family and few friends, Schardt was neither in acute pain nor suffering from life-threatening illness. ${ }^{170}$ She did have some trouble moving around her apartment and, with no social supports, her eventual placement in a nursing home appeared inevitable. What made this prospect especially unbearable to Schardt was her fear of strangers and her "low tolerance for those less clever than she was." "171 With the aid of Roger Kusch, a well-known German crusader for assisted suicide and a sort of Teutonic Jack Kevorkian, ${ }^{172}$ Schardt consumed a deadly brew of medications and ended her life.

In Germany and Switzerland, assisted suicide is not a crime if the accomplice is not acting out of self-interest. ${ }^{174}$ In the Netherlands and Belgium, voluntary assisted euthanasia, as well as physician-assisted suicide, is practiced legally. ${ }^{175}$ After the death of Schardt, German

166. Id. at 362 .

167. Id. Loss of appetite also occurs in some patients who are approaching death.

168. Mark Lander, Assisted Suicide of Healthy 79 Year-Old Renews German Debate on Right to Die, N.Y. TIMES, July 3, 2008.

169. Id.

170. Id.

171. Id

172. Id. Kevorkian was an assisted suicide zealot from Michigan who, without legal authority, performed euthanasia. He admitted to helping more than 130 people die. In 1999 , Kevorkian was convicted of second-degree murder in Michigan and sentenced to ten to twentyfive years in prison. "He was released in 2007, having agreed as a condition of parole not to participate in future suicides." Stern \& DiFonzo, supra note 20, at 120 n.206.

173. Lander, supra note 168.

174. Kimsma, supra note 47. Swiss law requires a medical consultation and informed consent on the part of the participant. See Christel Kucharz, Assisted Suicide Provokes Outcry in Germany, ABC NEWS, July 4, 2008, available at $\mathrm{http}: / /$ abcnews.go.com/International/story?id= 5309791 \&page $=1$.

175. Kimsma, supra note 47. See Victoria Hiley, In PuRsuit of a Good Death: REsPonding to Changing SENSIBILITIES IN THE ConteXt OF THE Right to Die Debate 175-224 (Jan. 2008) (Doctoral Thesis, Univ. of Sydney) (describing assisted euthanasia and physicianassisted suicide in the Netherlands), available at http://ses.library.usyd.edu.au/bitstream/2123/ 
Chancellor Angela Merkel declared her opposition to all forms of assisted suicide and called for "strict legislation."176 Eugen Brysch, director of the German Hospice Foundation, averred that shoddy treatment of the aging was the real concern in need of confrontation: "The fear of nursing homes among elderly Germans is far greater than the fear of terrorism or the fear of losing your job." "177 For a largely European market, a Swiss euthanasia group, Dignitas, offers death with dignity to the terminally ill by means of lethal medication. ${ }^{178}$ In the last ten years, 500 Europeans have crossed the Swiss border in search of assistance in ending their lives. ${ }^{179}$ Many Germans were among them. ${ }^{180}$

Dignitas figured prominently in the death of Sir Edward Downes, distinguished British orchestra conductor, and his wife of fifty-four years. ${ }^{181}$ Downes, eighty-five, suffered from increasing blindness and deafness but no terminal illness. ${ }^{182}$ His wife, seventy-four, was in the last stages of terminal cancer. ${ }^{183}$ Together with their children, the couple journeyed to Zurich where, aided by Dignitas, Lord and Lady Downes consumed a lethal concoction and, holding hands, lay down side by side, dying within ten minutes. ${ }^{184}$ "It is a very civilized way to end your life," said their son, "and I don't understand why the legal position in this country doesn't allow it." 185 Friends of Edward Downes described him as "completely rational,"186 and termed the couple's death "typically brave and courageous." 187 Others were discomfited by the fact that Downes was not imminently dying at the time of his decision. ${ }^{188}$ In Britain, Sir Edward's case was one of a known few in which a non-terminally ill spouse had chosen to die with one who was. ${ }^{189}$

As of July 2009, 117 Britons had traveled to Dignitas' Zurich-based clinic for help in ending their lives. ${ }^{190}$ None of the friends and relatives accompanying them has been prosecuted. Still, after the deaths of Lord

2611/2/Thesis\%20V\%20Hiley\%20In\%20Pursuit\%20of\%20a\%20Good\%20Death.pdf.

176. Kucharz, supra note 174.

177. Lander, supra note 168.

178. Id.

179. Id.

180. Kucharz, supra note 174.

181. John F. Burns, With Help, Conductor and Wife Ended Lives, N.Y. TIMES, July 15, 2009, available at $\mathrm{http} / / / \mathrm{www}$.nytimes.com/2009/07/15/world/europe/15britain.html.

182. Id.

183. Id.

184. Id.

185. Id. (quoting Caractacus Downes).

186. Id. (quoting Richard Wigley).

187. Id. (quoting Jonathan Graves).

188. Id.

189. Id.

190. Id. 
and Lady Downes, even the chief executive of Britain's Dignity in Dying pressed for limitations on travel abroad for purposes of seeking aid in dying. ${ }^{191}$ In July 2009 , a bill to allow people to travel abroad in furtherance of assisting others to die, subject to certain safeguards, was defeated in the House of Lords. ${ }^{192}$ In that same month, the British Medical Association voted against legalization of physician aid in dying. ${ }^{193}$

In Britain, assisting a suicide remains a criminal offense. ${ }^{194}$ But even more unnerving than the threat of prosecution was the uncertainty regarding standards under which one might be criminally liable for assisting a suicide. Debbie Purdy, age forty-six, had primary progressive multiple sclerosis. ${ }^{195}$ If she chose to end her life, she wanted to know whether her husband would be prosecuted for accompanying her to Dignitas. ${ }^{196}$ She brought her case to the House of Lords and, in July 2009 , won a groundbreaking victory. ${ }^{197}$ Ruling that "the current lack of clarity is a violation of the right to a private and family life," 198 the House of Lords ordered the Director of Public Prosecutions to issue guidelines governing criminal proceedings against assisted suicide. The resulting Interim Policy for Prosecutors in respect of Cases of Assisted Suicide appeared in September 2009. ${ }^{199}$ To aid in the decision-making process involving prosecution of assisted suicide, the policy proposes a list of factors to be considered. Among them are the age (whether over eighteen), capacity and the express wishes of the person seeking assisted death as well as whether he or she has a terminal illness, a severe and incurable disability or a severe degenerative physical condition. ${ }^{200}$ Prosecutors must also examine the type of relationship between persons seeking and providing assistance in dying (e.g., whether they are family members or close friends), the motivation for

191. Id.

192. Id.

193. Id.

194. Id.; see HrLEY, supra note 175, at 7-10 (describing the British legal approach).

195. Afua Hirsch, Debbie Purdy Wins 'Significant Legal Victory' on Assisted Suicide, guardian.co.uk, July 30, 2009, available at http://www.guardian.co.uk/society/2009/ jul/30/debbie-purdy-assisted-suicide-legal-victory.

196. Id.

197. Id.

198. Id.

199. The Crown Prosecution Service, Interim Policy for Prosecutors in respect of Cases of Assisted Suicide, If 19, (1)-(16), available at http://www.cps.gov.uk/consultations/as_policy. html.

200. Id. 
providing such assistance, and the prospect of coercion. ${ }^{201}$ The guidelines are silent as to the role of physicians in assisted suicide. ${ }^{202}$

Great Britain's Interim Policy is notable for including severe, incurable disability and degenerative physical condition in addition to terminal illness. In the Netherlands, with its far more liberal outlook on hastening death, requests by those not terminally ill are not uncommon, if not quite universally condoned. In 2001, a Dutch court of appeal set aside the acquittal of Dr. Philip Sutorius, a physician accused of helping a patient with no serious physical illness to die. ${ }^{203}$ The patient, an eighty-nine-year-old former member of the Upper House of Parliament, was "obsessed with his physical decline and hopeless existence," and had told Dr. Sutorius of his wish to die on multiple occasions. ${ }^{204} \mathrm{Dr}$. Sutorius was found guilty but no punishment was imposed, recognizing that he had acted out of great concern for his patient, with prudence and professionalism, and that he had freely reported the incident. ${ }^{205}$ Whether his conduct was legally defensible depended on the court's determination as to whether doctors possess the expertise to judge such matters of existential suffering. ${ }^{206}$ The court, relying on expert opinion, concluded that they do not ${ }_{3}$ and that Dr. Sutorius should have referred the patient to a therapist. ${ }^{207}$ The Royal Dutch Medical Association agreed with the judgment in drawing a line for physicians in terms of treatment of physical and mental suffering, but it maintained that medicine's role in regard to existential suffering was still uncertain. ${ }^{208}$ Dr. Sutorius appealed to the Supreme Court of the Netherlands, which

201. Id.

202. Id. On February 25, 2010, Keir Starmer, Britain's Director of Public Prosecutions, issued new guidelines for bringing criminal charges in matters of assisted suicide. Starmer called for the exercise of discretion in evaluating individual cases. In addition to the factors discussed in the text above, prosecutors must give special emphasis to the motive of the suspect, determining whether he was acting entirely out of compassion or with malicious intent. Gregory Katz, Assisted Suicide Guidelines in the UK, Feb. 25, 2010, available at http://www.cbsnews. $\mathrm{com} /$ stories $/ 2010 / 02 / 25 / \mathrm{health} / \mathrm{main} 6242846 . \mathrm{shtml}$. In accordance with these new guidelines, Starmer declined to bring charges against Caractacus Downes, son of Lord and Lady Downes, for accompanying his parents to the Zurich clinic where they ended their lives. Terming Lord and Lady Downes' decision "voluntary, clear, settled and informed," Starmer further found the actions of Caracterus Downes to have been "wholly motivated by compassion." David Brown, Children of Sir Edward Downes Will not be Charged Over His Suicide, Mar. 20, 2010, available at http://www.timesonline.co.uk/tol/news/uk/crime/article 7069252.ece (quoting Keir Starmer).

203. Tony Sheldon, "Existential" Suffering Not a Justification for Euthanasia, 323 (7326) BRIT. MED. J. 1384 (2001), available at http://www.pubmedcentral.nih.gov/articlerender. fcgi?artid=1121852 [hereinafter Sheldon, "Existential" Suffering].

204. Id.

205. Id.

206. Id.

207. See Hiley, supra note 175 , at 194.

208. Sheldon, "Existential" Suffering, supra note 203. 
affirmed the conviction, holding that there must be a medical condition leading the patient to experience unbearable suffering. ${ }^{209}$

In a 2005 survey in the Netherlands, doctors reported receiving about 400 assisted dying requests a year for primarily existential reasons. ${ }^{210}$ Most of these solicitations came from elderly patients with ailments but no acute or chronic illnesses, almost all of whom have lost a spouse or who are single and socially isolated. ${ }^{211}$ About three percent of the physicians surveyed complied with these requests. ${ }^{212}$ G.K. Kimsma, a Dutch physician, regarded euthanasia for existential suffering philosophically understandable but beyond the reach of medicine. ${ }^{213}$ Nevertheless, although he would not actively assist such a patient himself, he would counsel the patient on the use of sleeping pills and a plastic bag to aid in suffocation. ${ }^{214}$ Without explicitly endorsing the patient's decision, Dr. Kimsma would consider it his "professional duty as a family physician to help and support the patient during the process, and the family afterwards."

In the United States, such open-mindedness and candor on the part of doctors is rare, even in Oregon and Washington, and even in cases with far more objective indicia of suffering. The existential plight of those not "dying of anything"216 is troubling and, at present, probably too fraught with subjectivity to invite many broadly acceptable medical and policy solutions. It is crucial, however, to recognize the existential dynamic in all suffering, especially in elderly patients dealing with loss, loneliness and increasing frailty.

Most physicians do not concern themselves with the care of dying patients and, historically, have been reluctant to do so. ${ }^{217}$ Perhaps, as the sociologists hypothesize, doctors have an inordinate fear of death. ${ }^{218}$ For whatever reason, death and medicine do not sit well together. If doctors

209. See Tony Sheldon, Being "Tired of Life" Is Not Grounds for Euthanasia, 326 (7380) BRIT. MED. J. 71 (2003), available at http://www.pubmedcentral.nih.gov/articlerender.fcgi? blobtype $=$ html\&pubmedid=12521966; HrLeY, supra note 175, at 194-95. The continuing complexity of this issue may be seen in the Royal Dutch Medical Association inquiry launched in 2002 into whether physicians should be allowed to help patients die if they are neither terminally ill nor suffering from a psychiatric illness but are rather "suffering through living." Id. at 201. The resulting 2005 Report concluded that these cases of existential suffering are indeed within a physician's area of competence. Id.

210. Kimsma, supra note 47.

211. Id.

212. $I d$.

213. Id.

214. Id.

215. Id.

216. Gross, supra note 147.

217. McCue, supra note 4.

218. Id. at 1041. 
are disinclined to ponder the subject of dying, they are even less disposed to discuss it openly with their patients.

\section{DOCTOR-PATIENT DISCOURSES ON DYING}

"Who taught you all this, Doctor?"

The reply came promptly: "Suffering"

Albert Camus. $^{219}$

Physician: One upon whom we set our hopes when ill and our dogs when well.

Ambrose Bierce 220

\section{A. Speaking of Death}

When, in the nineteenth century, the doctor dislodged the preacher at the deathbed, a paradox was born. The growing primacy of medical technique had created "the categorical imperative to minister hope . . . irrespective of the fact that the patient was hopelessly dying." 221 To this paradox we owe, at least in part, a legacy of aggressive and often futile medical procedures for the dying, such as ventilation, resuscitation, and the drawing of our final breaths amidst the beeping and blinking of machinery in sterile hospital rooms and intensive care units. It is all too easy to blame the doctors and not our boundless appetite for miracles. But even the profession's eminent own have remarked upon the torments caused in the name of treatment and the fact that "the relief of suffering . . . is considered one of the primary ends of medicine by patients and the general public, but not by the medical profession."222

The practice of holding out hope to the hopeless gave little instruction in dealing with those who were clearly beyond help. Until the end of the twentieth century, medical students were basically unschooled in end of life processes. ${ }^{223}$ Patients near death were studiously avoided on morning rounds, isolated as symbols of shameful medical failure. ${ }^{224}$ Pain in the dying was grossly, even callously, undertreated, with medications given "in doses too small and too far apart."225 The growth of the hospice movement contributed to better

219. Albert Camus, The Plague 128-29 (Stuart Gilbert ed., 1948).

220. BIERCE, ThE COLleCtEd WRITINGS, supra note 29, at 325.

221. LAVI, supra note 11 , at 56.

222. CASSELL, supra note 27, at 32.

223. See Marcia Angell, The Quality of Mercy, in QuILL \& BATTIN, supra note 31, at 16.

224. Id.

225. Id. 
pain relief and the rise of palliative care as a medical specialty. ${ }^{226}$ Lessons learned from the Oregon assisted dying experience also promoted greater awareness and sensitivity regarding end of life matters. ${ }^{227}$ Yet, for many doctors, discussing death with their severely ill patients remains difficult and disconcerting.

In a study of conversations between eight different oncologists and a role-playing "dying" woman, only one doctor even uttered the word "death." ${ }^{228}$ There are a number of reasons why doctors avoid specific use of terms like "death" and "dying" in speaking with patients. ${ }^{229}$ They do not wish to cause distress to the patient or face their own unease at dealing with a patient who has just received a dire prognosis. ${ }^{230}$ Doctors who have developed long-term, close relationships with patients may have trouble dealing with their own sense of grief and loss. ${ }^{231}$ Further, both patients and doctors may view mention of death as "an admission of failure or of giving up."

Patients who are told they have a terminal or chronic illness feel "trapped between reality and possibility."233 Euphemisms might cushion the blow of bad news, but they also mislead and confuse. ${ }^{234}$ Deciding when and if to invoke the "language of hope" is "excruciatingly difficult," mainly because doctors are uncertain about prognosticating and mindful of how often they are wrong. ${ }^{235}$ Couching discussions in terms bleaker than necessary creates "false hopelessness," believed to be even more debilitating than false hope. ${ }^{236}$ On the other hand, the cultivation of false hope may induce patients to try "last-ditch" and "unproven" therapies that are financially and emotionally depleting. ${ }^{237}$ A "terrified patient and well-intended doctor" may so fervently desire a good outcome that "what emerges is a collective denial about the patient's condition.,"238

In 2010, the journal Cancer published the results of a large, multiregional study examining the timing of doctor-patient end of life

226. Id. at 19 .

227. Cassell, When Suffering Patients Seek Death, in QuILL \& BATTIN, supra note 31, at 87 .

228. Scott Berry, Just Say Die, 26 J. CliniCal OnCology 157, 157 (2008).

229. Id.

230. Id. at 158 .

231. Id.

232. Id.

233. Jan Hoffman, Doctors ' Delicate Balance in Keeping Hope Alive, N.Y. TIMES, Dec. 24, 2005, at A1, available at http://www.nytimes.com/2005/12/24/health/24patient.html.

234. Berry, supra note 228 , at 158 .

235. Hoffman, supra note 233.

236. Id.

237. Id.

238. Id. 
discussions. ${ }^{239}$ The research showed that many doctors delay discussing end of life options with terminally ill patients who are still feeling well, "and instead wait for the onset of symptoms or until there are no more nonpalliative treatments to offer."240 Younger physicians, perhaps due to greater emphasis on palliative care in medical training, are more likely to discuss end of life choices with their patients than older physicians. ${ }^{241}$ The authors caution that "discussions of prognosis are not synonymous with advance care planning,"242 and may as readily be viewed by doctors as an opportunity to discuss potential treatments. ${ }^{243}$ Excessive treatment such as chemotherapy, even for cancers generally seen as unresponsive to such measures, causes further and unnecessary delay in end of life discussions. ${ }^{244}$ Dr. Nancy Keating, the study's lead author, explained, "These conversations are time-consuming and difficult. Some doctors may feel patients will lose hope. It's easier to say, 'Let's try another round of chemotherapy,' instead of having a heart-to-heart discussion."

As stressful as such conversations are, doctors may find consolation in knowing how beneficial a realistic end of life discussion with a patient can be. A study by Wright et al. concluded that discussing end of life issues with their doctors helped patients accept their illnesses as terminal, leading them to forego aggressive, often harmful, lifeextending interventions and choose hospice and palliative care instead. ${ }^{246}$ Patients who did not engage in these discussions opted for more aggressive medical treatments and delayed their entry into hospice care as late as one week before death, thus worsening the quality of life remaining. 247

239. Nancy L. Keating et al., Physician Factors Associated with Discussions About End of Life Care, CANCER, EARLY VIEW, available at http://www3.interscience.wiley.com/journal/ 123237834/abstract?CRETRY=1\& SRETRY=0 (last visited Mar. 11, 2010).

240. Id. at 6 .

241. Id. at 7 .

242. Id.

243. Id.

244. Id.

245. Denise Grady, Facing End-of-Life Talks, Doctors Choose to Wait, N.Y. TrMES, Jan. 12, 2010, available at http://www.nytimes.com/2010/01/12/health/12seco.html? emc=etal.

246. Alexi Wright et al., Associations Between End-of-Life Discussions, Patient Mental Health, Medical Care Near Death, and Caregiver Bereavement Adjustment, 300 J. AMER. MED. Ass'N 1665, 1668 (2008); see also Marie Bakitas et al., Effects of a Palliative Care Intervention on Clinical Outcomes in Patients With Advanced Cancer, 302 J. AMER. MED. Ass'N 741, 748 (2009) (describing nurse-led intervention for patients newly diagnosed with cancer which improved mood and quality of life. The project emphasized patient empowerment and communication of values, priorities and treatment preferences, particularly "during times when anticancer treatments were less likely to halt disease progression or alleviate symptoms.").

247. Wright et al., supra note 246 , at $1670-71$. 
Perhaps the best guidance on handling painful patient-doctor communications is to practice what Timothy Quill and Christine Cassell call "nonabandonment." 248 Patients will feel more at ease in revealing fears about death "if health care providers have the courage to ask about them."249 Patients and their families take solace in knowing that their physicians are "willing to face the unknown together with them, and to address any extremes of suffering that may arise."250 Fear of future pain and suffering is among the most powerful inducements to pursue a hastened death. Indeed, Pearlman and his colleagues suggest that a patient's request for aid in dying should spark a thorough assessment of the patient's motives as well as ways to attend to and mitigate the patient's suffering. ${ }^{251}$ But how do doctors typically respond when patients ask them for advice and assistance in planning their own deaths?

\section{B. Doctors and Patients Speaking of Death}

At the outset, it should be noted how hard it is for patients to approach the subject of assisted dying with their physicians. Even an attempt to find out more about a serious prognosis causes patients to feel "flustered," "apprehensive and intimidated," "cognizant of the physician's limited time," "unable to find the right words," and "afraid of crying." 252 In broaching the subject of assisted dying, patients often sense resistance and aversion in their doctors, turning the conversations into skirmishes and limiting their access to information. ${ }^{253}$ One patient, seeing how unnerved her oncologist was by the mention of hastened death, felt compelled to "change the subject for his sake."254 "I learned that he's a baseball fan," the patient said, "and much more comfortable if I change the topic to baseball. It's awful when you have to try and make them feel comfortable, but that's the way it is." clinicians, allusions to assisted suicide provoke such strong emotional reactions that they foreclose further discussion. One neurologist declared that physician aid in dying was "a terrible thing and the wrong

248. Timothy E. Quill \& Christine K. Cassell, Nonabandonment: A Central Obligation for Physicians, in QUILL \& BATTIN, supra note 31, at 24, 32.

249. Id.

250. Id.

251. Pearlman et al., supra note 117 , at 238 .

252. Mercedes Bern-Klug, The Ambiguous Dying Syndrome, 29 HEALTH \& Soc. WORK 55, $62(2004)$.

253. Anthony L. Back, Doctor-Patient Communications about Physician-Assisted Suicide [hereinafter Back, Doctor-Patient Communications], in QuILL \& BATTIN, supra note 31, at 102, 103. 
thing to do."256 The conversation, said the patient, "was kind of awful.,"257

Because requests for aid in dying are also made in states where it is illegal, doctors often worry about placing their careers in jeopardy. Some behave "as if discussions of assisted suicide, in and of themselves, [are] illegal and dangerous. ${ }^{258}$ Patients are left at a loss as to who they can safely approach. One patient, upon resolving to bring up the subject of assisted dying with her physician said, "I went in with fear and trembling... It's a real crap shoot.".259

For one patient, the penalty for bringing up the subject of assisted dying was more pain. Non-terminally ill patients seeking lethal prescriptions pose especially thorny problems for physicians. An MS patient, whose pain was becoming increasingly hard to control, attempted to discuss his interest in hastened death with his care team. According to his wife, the doctors responded by becoming "even more stingy with the [pain] medications because they were very worried that he was going to use the medications to kill himself."260 At times, a doctor who appears sympathetic to a patient who seeks help in dying can cause harm by his unacknowledged ambivalence. In one instance, a patient, upon reading Final Exit, ${ }^{261}$ learned that the barbiturate secobarbitol was the recommended chemical means to end one's life. The doctor was reluctant to prescribe this medication and instead prescribed flurazepam, a less potent sedative hypnotic agent. ${ }^{262}$ After accumulating a sufficient supply of medication, the patient, in the presence of her family, took the pills and went to sleep. "And then the horrible part started," explained her daughter, "because then she wouldn't die." "263 After an "agonizing" eleven hour vigil, during which the family was "freaking out," the patient finally succumbed without awakening. ${ }^{264}$

Death with dignity is not blanketly guaranteed, even in Oregon. State law requires a second medical consultation to confirm the patient's terminal status, as well as voluntariness and mental capacity to engage in assisted dying. ${ }^{265}$ One patient who had the full approval of her

256. Id.

257. Id.

258. $I d$.

259. Id.

260. Helene Starks et al., Family Member Involvement in Hastened Death, 31 DEATH STUDIES 105, 118 (2007).

261. DEREK HuMPHRY, FINAL EXIT (1991). The book is a how-to manual on committing suicide.

262. Starks et al., supra note 260 , at 113 .

263. Id.

264. Id.

265. OR. REV. STAT. § 127.820 (2009). 
primary doctor, found the second physician to be "dragging her feet," perhaps because "it was a moral issue with her." ${ }^{, 66}$ Despite the patient's repeated insistence that she wanted to go through with her plan, the doctor further procrastinated by requiring her to undergo a psychiatric evaluation. ${ }^{267}$ This alone was burdensome because the patient could no longer walk. At the psychiatrist's office, the patient played the requisite word games, answered a multitude of questions and, at the end, looked at the psychiatrist and asked, "Well, did I pass?"268 The psychiatrist was moved to tears because the patient's "idea of winning and achieving was so she could take her own life."269 Although, for this patient, compliance with the law was somewhat onerous, the statute did permit her doctor to be present at her death. A gentle, reassuring presence, he confirmed that the patient's act was voluntary and remained with her and her family while she ingested the medication. ${ }^{270}$ The patient died within fifteen minutes. ${ }^{271}$

Where physician assisted dying is illegal, willing patients and doctors often collude in secrecy, avoiding "explicit discussions of medication use" and relying on indirect, sometimes cryptic instructions. ${ }^{272}$ In such cases, patients often seek advice from groups like Compassion \& Choices. But the rarely acknowledged fact is that, legal or not, physicians assisted in their patients' deaths in the past and they continue to do so. ${ }^{273}$ Forty or fifty years ago, young doctors knew that older, more experienced physicians might administer large doses of morphine to suffering patients and speed up their deaths. This occasional practice, along with the tacit abandonment of dying patients, "had no place in the curriculum or in the discourse of the medical profession at large." 274 It simply was not talked about.

As patients, we sometimes long for some small sign that doctors feel for us, that our pain and suffering have struck a chord and resounded in their own experience. Empathy shown in doctor-patient interactions is believed to improve patient satisfaction as well as "adherence to physicians' recommendations." "275 Yet, as determined by one recent

266. Starks et al., supra note 260 , at 120 .

267. OR. REV. STAT. $§ 127.820$. Such evaluations are required when the doctor suspects the "patient may be suffering from a psychiatric or psychological disorder or depression causing impaired judgment." OR. REV. STAT. $\$ 127.800(5)$.

268. Starks et al., supra note 260 , at 120-21.

269. Id.

270. Id. at 121 .

271. Id.

272. Back, Doctor-Patient Communications, in QuILL \& BATTIN, supra note 31, at 109.

273. Cassell, When Suffering Patients Seek Death, in QuILL \& BATTIN, supra note 31, at 75, 77.

274. Angell, The Quality of Mercy, in QuILL \& BATTIN, supra note 31, at 16.

275. Diane S. Morse et al., Missed Opportunities for Interval Empathy in Lung Cancer 
study, empathy is apparently not a priority in medical practice. This analysis of doctor interactions with lung cancer patients showed that, out of 384 opportunities to respond empathically, doctors ignored all but $10 \%$ of them. ${ }^{276}$ Physicians "provided little emotional support," preferring to take refuge in "biomedical questions and statements."

When faced with requests for assisted dying, many, if not most doctors hesitate to participate, and they should not feel coerced or compelled to do so. ${ }^{278}$ But by silencing their patients' fears and concerns with peremptory denials, they pass up critical opportunities for humane, compassionate intervention. The building of a "therapeutic alliance" can be as reassuring as a prescription for lethal drugs. ${ }^{279}$ Sometimes, patients feel they are sorely in need of both.

\section{LAW, MEDICINE, AND THE ART OF DYING}

I never spoke with God,

Nor visited in heaven;

Yet certain am I of the spot

As if the chart were given.

Emily Dickinson ${ }^{280}$

First one birdcall, then three, then a chorus from down by the river. This would be a good time to die with the bottle of pills and a water jug handy, all to the gathering density of birdsong... Jim Harrison ${ }^{281}$

\section{A. Law in the Service of Limitation}

In 1997 the U.S. Supreme Court, in Washington v. Glucksberg, unanimously declined to recognize a right to assistance in committing suicide as a fundamental liberty interest protected by the Due Process Clause. ${ }^{282}$ Since then, reams of legal commentary, often inscribed with

Communications, 168 ARCH. INTERN. MED. 1853, 1853 (2008).

276. Id.

277. Id.

278. Wendy Johnston \& Paul Bascom, Physicians' Role in Physician-Assisted Suicide Discussions, 6 VIRTUAL MENTOR (Amer. Med. Ass'n J. Ethics) (2004), available at http:// virtualmentor.ama-assn.org/2004/08/ccas1-0408.html.

279. Back, Doctor-Patient Communications, in QULL \& BATTIN, supra note 31, at 114.

280. Emily Dickinson, I Never Saw a Moor, in The Collected PoEMS OF EMILY DICKINSON, supra note 1 , at 1052.

281. Jim HARRISON, THE ROAD HOME 428-29 (1998).

282. Washington v. Glucksberg, 521 U.S. 702, 728 (1997). On the same day, the Court decided Vacco v. Quill, 521 U.S. 793 (1997), turning away an Equal Protection Clause 
words like "dignity" and "autonomy," have wrapped themselves around the assisted dying debate. ${ }^{283}$ But while Glucksberg effectively put an end to rights talk, at least on the federal level, it did little to elucidate the issues. Writing on the case's tenth anniversary, Yale Kamisar called Glucksberg "the most confusing and the most fragile 9-0 decision in Supreme Court history." 284 In neither the majority nor in the five concurring opinions did the justices correctly or coherently define the questions presented. ${ }^{285}$ The plaintiffs, asserted Kamisar, were not seeking a broad-based right to commit suicide, but "only a right to a physician's assistance in doing so," and in "very special circumstances," namely, when the patient is terminally ill. ${ }^{286}$

Kamisar also noted the difficulty of reconciling Glucksberg with the Supreme Court's more recent decision in Lawrence v. Texas. ${ }^{287}$ Unlike Glucksberg, Lawrence generously interpreted the reach of the Due Process Clause, extending its protections to homosexuals engaged in consensual sodomy, ${ }^{288}$ thus overruling Bowers v. Hardwick. ${ }^{289}$ Declaring our most intimate choices to be immune from state intrusion, the Court endorsed as inviolate the rights to privacy and dignity in making those choices. ${ }^{290}$ The Lawrence court's rapturous endorsement of the "mystery of human life" language in Planned Parenthood $v$. Casey $^{291}$ seemed to breathe new life into the privacy and autonomy

challenge to New York's statute criminalizing assisted suicide, and holding that the difference between the withdrawal of life support and the provision of life-ending drugs justifies disparate legal treatment. Id. at 801-02. See Stern \& DiFonzo, supra note 20, at 117-20 (analyzing Glucksberg and Quill).

283. See, e.g., Erwin Chemerinsky, Washington v. Glucksberg was Tragically Wrong, 106 Mich. L. REv. 1501, 1503 (2008); Daniel O. Conkle, Three Theories of Substantive Due Process, 85 N.C. L. Rev. 63, 90 (2006); Kurt Darr, Physician-Assisted Suicide: Legal and Ethical Considerations, 40 J. HEALTH L. 29, 41 (2007); Barbara J. Evans, Judicial Scrutiny of Legislative Action that Presents Bioethical Dilemmas, 16 VA. J. Soc. PoL'Y \& L. 179, 214 (2008); B. Jessie Hill, The Constitutional Right to Make Medical Treatment Decisions: A Tale of Two Doctrines, 86 TEx. L. REv. 27 (2007); Maxine D. Goodman, Human Dignity in Supreme Court Constitutional Jurisprudence, 84 NEB. L. REv. 740, 741 (2006); Youngjae Lee, Valuing Autonomy, 75 FordHAM L. REV. 2973, 2973 (2007); Mattei Ion Radu, Incompatible Theories: Natural Law and Substantive Due Process, 54 VILL. L. REV. 247, 257 (2009); Neomi Rao, On the Use and Abuse of Dignity in Constitutional Law, 14 CoLuM. J. EuR. L. 201 (2008); Mark S. Stein, Necessity, Not Autonomy, 86 TEx. L. REV. 15, $20-21$ (2008); John C. Toro, The Charade of Tradition-Based Substantive Due Process, 4 N.Y.U. J.L. \& LIBERTY 172, 189 (2009).

284. Yale Kamisar, Can Glucksberg Survive Lawrence? Another Look at the End of Life and Personal Autonomy, $106 \mathrm{MrCH}$. L. REV. 1453, 1460 (2008).

285. Id. at $1459-60$.

286. Id. at 1460-61.

287. Lawrence v. Texas, 539 U.S. 558 (2003).

288. Id. at 574.

289. Bowers v. Hardwick, 478 U.S. 186 (1986).

290. Lawrence, 539 U.S. at 575.

291. Id. at 574 (quoting Planned Parenthood v. Casey, 505 U.S. 833, 851 (1992)). The 
arguments in support of the right to physicians' assistance in dying. ${ }^{292}$ Nevertheless, in the decade following Glucksberg, no state legislature legalized physician aid in dying, and no state court unearthed a right to the practice in its own constitution. ${ }^{293}$

In December 2008, a Montana district court declared that state constitutional rights to privacy and dignity "mandate that a competent terminally ill person has the right to choose to end his or her life."294 The plaintiff, terminally ill with leukemia, challenged the constitutionality of the state's homicide statutes as applied to physician assisted suicide. The court based its decision on the Montana constitution's individual dignity clause $\mathrm{s5}^{295}$ and the right to privacy clause, ${ }^{296}$ noting that Montana's "stringent protections of its citizens' right to privacy" exceed even those of the U.S. Constitution. ${ }^{297}$ On appeal, the Montana Supreme Court reviewed the trial court's judgment de novo, choosing to resolve the issue "at the statutory rather than the constitutional level." 298 The question presented was "whether the consent of the patient to his physician's aid in dying could constitute a statutory defense to a homicide charge against the physician." ${ }^{299}$ The court concluded that a terminally ill patient's consent to physician aid in dying, as long as it is competent and voluntary, does not violate public policy. ${ }^{300}$ The patient's "peaceful and private act"301 of ingesting doctor-prescribed medication is "not comparable to the violent, peacebreaching conduct" ${ }^{\prime 302}$ that threatens the public welfare. Moreover,

relevant passage in Casey pertained to personal decisions concerning marriage, procreation, contraception, family relationships, child rearing, and education:

These matters, involving the most intimate and personal choices a person may make in a lifetime, choices central to personal dignity and autonomy, are central to the liberty protected by the Fourteenth Amendment. At the heart of liberty is the right to define one's own concept of existence, of meaning, of the universe, and of the mystery of human life.

Id.

292. Kamisar, supra note 284 , at $1458-59$.

293. Id. at 1467.

294. Baxter v. Montana, No. ADV-2007-787, 2008 WL 6627324, at *17 (Mont. Dist. Ct. Dec. 5, 2008).

295. MonT. Const. art. II, $\S 4$ (stating "[t]

296. MONT. CONST. art. II, $\S 10$ (stating "[t] he right of individual privacy is essential to the well-being of a free society and shall not be infringed without the showing of a compelling state interest").

297. Baxter, No. ADV-2007-787, at 15.

298. Baxter v. Montana, 224 P.3d 1211, 1215 (Mont. 2009).

299. Id.

300. Id. at 5-6, 12-13.

301. Id. at 7 .

302. Id. 
although the patient and physician "work together to create a means by which the patient can be in control of his own mortality,"303 the doctor "is not directly involved in the final decision or the final act." ${ }^{, 304}$ For further statutory guidance, the court turned to Montana's Terminally Ill Act ${ }^{305}$ which expressly shields physicians who follow a patient directive to withhold or terminate life-sustaining treatment from civil criminal liability. ${ }^{306}$ The court reasoned that, if doctors are immunized from such direct acts as disconnecting a ventilator or withholding treatment, it is neither inconsistent nor offensive to public policy for terminal patients to self-administer life-ending medication without a physician's direct or immediate assistance. ${ }^{307}$

Baxter's holding substantiates Montana's "long-standing, evolving and unequivocal" respect for patient autonomy at the end of life, as evidenced in the state's Terminally Ill Act. ${ }^{308}$ That this deference is rooted in statutory entitlement rather than constitutional mandate signals a new direction in end of life policymaking. A case quite similar to Baxter is currently pending in the Superior Court of Hartford, Connecticut. ${ }^{309}$ In that action, plaintiff doctors seek both a declaratory judgment that physician aid in dying does not constitute assisting a suicide under Connecticut's manslaughter statute, ${ }^{310}$ and a permanent injunction against state prosecution of doctors who provide physician aid in dying to terminally ill individuals. Under Oregon and Washington's Death with Dignity laws, physician aid in dying is differentiated from suicide, assisted suicide, active euthanasia, mercy killing, and homicide. ${ }^{311}$ States seeking to legitimate physician aid in dying may no longer be mining constitutionally-based notions of privacy and dignity for inspiration. Shielding doctors from civil and criminal liability, especially in conjunction with existing state laws that

303. Id.

304. Id. (emphasis in original).

305. MONT. CODE ANN. § 50-9-204 (2009).

306. Id.

307. Baxter, 224 P.3d at 1220. Whether a distinction exists between withdrawing or withholding life-sustaining treatment and physician-aided death has long been a source of contention in the assisted dying debate. See, e.g., David Orentlicher, The Alleged Distinction Between Euthanasia and Withdrawal of Life-Sustaining Treatment: Conceptually Incoherent and Impossible to Maintain, 1998 U. ILL. L. REV. 837-60. While Baxter removes this distinction, the U.S. Supreme Court, in Vacco v. Quill, 521 U.S. 793, 801 (1997), firmly declined to abandon it: "when a patient refuses life-sustaining medical treatment, he dies from an underlying fatal disease or pathology; but if a patient ingests lethal medication prescribed by a physician, he is killed by that medication."

308. Baxter v. Montana, 244 P.3d at 248 (citing Title 50, Chapter 9, MCA).

309. Blick v. Div. of Criminal, HHD-CV-09-5033392-S (Sup. Ct. Conn., filed Oct. 6, 2009).

310. ConN. Gen. STAT. § 539-56(a).

311. ORE. ReV. Stat. $\S 127.880$; REV. CODE WASH. $\S 70.245 .180$. 
explicitly protect patient autonomy, may furnish a more workable, pragmatic approach to assisted dying legislation. Other than the Baxter trial court, no other state court has acknowledged a constitutional right to assisted suicide. ${ }^{312}$

Oregon voters approved the Oregon Death with Dignity Act in $1994 .^{313}$ In 2008, Washington voters followed suit and enacted a virtually identical statute. ${ }^{34}$ To date, these citizen initiatives stand alone, and no state legislature has passed legislation permitting assisted suicide. Both statutes require oral and written requests by the patient, verification as to competency and terminal illness by an attending and consulting physician, and a referral for counseling if the doctor suspects that the patient's judgment is impaired by a psychiatric or psychological disorder or depression. ${ }^{315}$ Both statutes limit the conferring of a dignified death to the terminally ill and, thus, the definitively dying. ${ }^{316}$ They define an illness as terminal when it is "incurable," "irreversible," and likely to "produce death within six months."317" Baxter defines terminal illness only insofar as it alludes to statutory language pertaining to "incurable or irreversible condition.",318

Sometimes diseases far outlast the patient's coping capabilities. Amyotrophic Lateral Sclerosis (ALS) patients with less than six months to live may have already "lost the use of their hands and have such difficulty swallowing that taking oral medication without assistance is no longer possible." ${ }^{319}$ Further, terminal illness rarely conforms to

312. The Florida Supreme Court upheld a statute prohibiting assisted suicide, reasoning that any asserted privacy interest was outweighed by State's compelling interests in preserving life, preventing suicide, and maintaining integrity of medical profession. Krischer v. McIver, 697 So. 2d 97 (Fla. 1997). The Alaska Supreme Court reached a similar conclusion, upholding that state's manslaughter statute against a constitutional attack on privacy grounds mounted by mentally competent, terminally ill adults who sought to have their physicians declared exempt from prosecution for the purpose of assisting them to commit suicide. Sampson v. Alaska, 31 P.3d 88 (Alaska 2001). Similarly, a California Court of Appeal held that a terminally ill individual's constitutional rights to privacy and to refuse medical attention did not extend to a right to an assisted suicide. Donaldson v. Lungren, 4 Cal. Rptr. 2d 59 (Cal. Ct. App. 1992). Finally, the Colorado Court of Appeals held that the First Amendment's Free Exercise Clause would not prevent the state from enforcing the statute making it manslaughter to intentionally cause or aid another person's suicide. Sanderson v. Colorado, 12 P.3d 851 (Colo. App. 2000).

313. OR. Rev. STAT. $\S 127.800$ (2000) (Oregon Death with Dignity Act); see Stern \& DiFonzo, supra note 20, at 125 (describing the process of enactment). In 1997, Oregon voters defeated a measure to repeal the Act by an even larger margin than the majority originally supporting it. Stern \& DeFonzo, supra note 20, at 125.

314. WASH. REV. CODE $\S \S 70.245$ (2008) (Washington Death with Dignity Act).

315. OR. REV. STAT. $\$ 127.800$; WASH. REV. CODE $§ 70.245$; see Stern \& DiFonzo, supra note 20, at 125-30 (analyzing the Oregon statute).

316. OR. REV. STAT. $\S 127.805$; WASH. REV. CODE $\S 70.245 .020$.

317. OR. REV. STAT. $\S 127.800$ (12); WASH. REV. CODE $\S 70.245 .010$ (13).

318. Baxter v. Montana, 224 P.3d at 1218 (citing MONT. CODE ANN. $§ 50-9-103(2)$ (2009)).

319. Ganzini et al., Attitudes of Patients, supra note 77, at 971. 
specific timelines, and the assumption that doctors can readily identify terminally ill patients is highly questionable. Cancer, the second leading cause of death in the United States, follows a generally recognizable pattern and its dying process is more predictable than in other diseases. ${ }^{320}$ Still, physicians find it difficult to recognize impending death, even in end-stage disease. ${ }^{321}$ Determining whether a patient is 'dying' of heart disease, America's leading cause of death, is not at all clear-cut, and doctors cannot pinpoint when continued medical intervention is no longer benefitting the patient. ${ }^{322}$ Patients with chronic obstructive pulmonary disease (COPD), congestive heart failure (CHP), and end-stage liver disease (ESLD) may "never experience a time during which they are clearly dying of their disease." ${ }^{23}$ Although the major causes of mortality have long since shifted from the acute to the chronic, "it can be difficult to determine at what point a progressive chronic illness becomes a terminal diagnosis." 324 Bern-Klug employs the term, "ambiguous dying syndrome" to denote a state of declining or severely compromised health with an indefinite prognosis. ${ }^{325}$ That "more people are dying in the penumbra of the ambiguous dying syndrome than die with a terminal illness" ${ }^{326}$ should radically alter our approaches to morbidity and mortality. Intractable suffering, both physical and existential, is not confined to the imminently dying. Yet, without ever really knowing "when the end of life begins," 327 we cling to the terminal illness standard, believing that it makes our assisted dying laws more palatable and more defensible.

There may come a time when we discard the notion of terminal illness as too amorphous to be workable. While the Montana Supreme Court's Baxter opinion retains this criterion, the lower court opinion it supplanted more expansively defined a patient eligible for assisted dying as one "who is suffering pain and the indignity of his disease ... and for whom palliative care is inadequate to satisfy his personal desire to die with dignity." 328 In a related vein, the euthanasia law of the

320. Bern-Klug, supra note 252, at 57-58.

321. Id. at 57.

322. Id.

323. Ellen Fox et al., Evaluation of Prognostic Criteria for Determining Hospice Eligibility in Patients With Advanced Lung, Heart, or Liver Disease, 282 J. AMER. MED. Ass'N 1638 (1999).

324. Bern-Klug, supra note 252 , at 58.

325. Id.

326. Id. at 61 .

327. Id. at 57.

328. Baxter v. Montana, No. ADV-2007-787, 2008 WL 6627324, at *20 (Mont. Dist. Ct. Dec. 5, 2008). 
Netherlands requires as a predicate not terminal illness, but unbearable suffering with no hope of improvement. ${ }^{329}$

Any opportunity to deepen and expand our understanding of illness and dying would inform our laws and policies in aid of suffering. We might have hoped that the Oregon experiment, now in operation for well over a decade, would have proven enlightening. It has, and it has not.

\section{B. What is the Matter with Oregon?}

Since Oregon's Death with Dignity Act (ODDA) took effect in 1997, 401 patients have ended their lives in accordance with the statute. ${ }^{330}$ Most of them were white, well-educated, between the ages of 55 and 84 , enrolled in hospice care, and medically insured. ${ }^{331}$ No outright abuses under the law have been reported, and critics' concerns about vulnerable individuals being induced or coerced to hasten their deaths have been quieted. ${ }^{332}$ Criticism of ODDA persists, however, principally regarding insufficient patient protections and the guarded way in which the Oregon Public Health Division (OPHD) doles out information about the law's operation. ${ }^{333}$

ODDA's eligibility criteria omit mention of patient suffering, unbearable or otherwise. Physicians who assist in suicide are not required to delve into their patients' motivations, nor are they expected to be skilled at recognizing and relieving physical and existential distress. ${ }^{334}$ Also absent from the statute is some familiarity with the notion that a patient who requests a lethal prescription presents an opportunity for empathy and reassurance, and for exploration of concerns about the dying process. Under ODDA, it seems, doctors focus less on the relief of suffering in dying patients than on matters of statutory compliance. ${ }^{335}$

329. See Kimsma, supra note 47, at 1; HILEY, supra note 175, at 199 (quoting the Royal Dutch Medical Association's view that medical ethics requires that a patient requesting euthanasia must be experiencing "suffering due to pain, whether or not based on a perceivable physical condition, or suffering due to a physical condition, or physical disintegration without pain that is unacceptable to the patient.").

330. Oregon Department of Human Services, Public Health Division, 2008 Summary of Oregon's Death with Dignity Act, at 2, available at http://egov.oregon.gov/DHS/ph/pas/docs/ year1 1.pdf [hereinafter Oregon Department of Human Services, 2008 Summary].

331. Id.

332. Courtney S. Campbell, Ten Years of "Death with Dignity," 22 NEw ATLANTIS (2008), at 39, available at http://www.thenewatlantis.com/publications/ten-years-of-death-with-dignity.

333. Herbert Hendin \& Kathleen Foley, Physician-Assisted Suicide in Oregon: A Medical Perspective, 106 MICH. L. REV. 1614, 1615 (2008).

334. Id. at 1615-16.

335. Id. at 1616. 
Hendin and Foley, two of ODDA's most vocal critics, insist that "desperation, anxiety, and depression underlie most requests for assisted suicide," 336 and that patients who pursue a hastened death "are usually telling us that they desperately need relief from their mental and physical distress and that without such relief they would rather die.",337 Such statements, while dramatic, are not supported by the research on actual assisted dying patients. Ganzini and Back have concluded that "the Oregon data do not support the assertion that patients who die by assisted suicide are depressed." 338 Starks and her colleagues noted that empirical studies of hastened death show that the typical participating patient is "not depressed." "339 In their drive to condemn the practice of assisted dying, Hendin and Foley's sardonic reference to Oregon as "the first state to legalize suicide as a treatment for medical illness," overstates their case. Hendin and Foley fail to distinguish between hopelessness and depression ${ }^{341}$ or between depression and something they call "current distress.",342 Nor do they cite any authority for their assertion that depression is "often precipitated by discovering a serious illness.",343

Elevating the role of depression in desire for hastened death at the expense of the more valid and more recognized role of existential suffering does not benefit dying patients. Plying them with "[s]upportive psychotherapy" and "antidepressant medication,"344 as Hendin and Foley recommend, may help some patients, but for others it can exacerbate an already overmedicalized death. Diagnosis and treatment of depressive disorders in the severely ill is important. It may even be advisable to make psychiatrists an integral component of the palliative care team. ${ }^{345}$ Clinicians, however, "should not assume the presence of depression, which might lead to ineffective, unnecessary, even harmful treatments." 346 Currently, there is no definitive research showing that treatment for depression reduces the desire for hastened death. ${ }^{34}$

336. Id. at $1623-24$.

337. Id. at 1623 .

338. Linda Ganzini \& Anthony Back, From the USA: Understanding Requests for Physician-Assisted Death, 17 Palliative MED. 113, 113 (2003).

339. Starks et al., supra note 91 , at 224.

340. Hendin \& Foley, supra note 333, at 1620.

341. Id.

342. Id. at 1621 .

343. Id. at 1636.

344. Id. at 1631 .

345. Scott A. Irwin \& Frank D. Ferris, The Opportunity for Psychiatry in Palliative Care, 53 CANADian J. PsYChIATRY 713, 716-18 (2008).

346. Ganzini et al., Why Oregon Patients Request Assisted Death, supra note 111, at 156.

347. Breitbart et al., supra note 64, at 2911; Ganzini et al., Prevalence of Depression, supra 
Under ODDA, physicians are charged with establishing whether patients requesting assisted dying are in need of mental health counseling. ${ }^{348}$ This schema may allow some "potentially ineligible" patients to acquire prescriptions for lethal drugs. ${ }^{349}$ Hendin and Foley aver that "physicians are not reliably able to diagnose depression."350 But measuring depression's effect on decision making is far more difficult than diagnosing it, "even by expert assessment." 351 As Ganzini and her colleagues have discovered, there are "no standards for determining competency to commit suicide."

In the care of dying patients, there can be no better safeguard against inappropriately hastened death than a long-term, in-depth doctor-patient relationship. Assisted dying is not just a means to "end a life at a particular moment, but more the end of a long process with an intensely emotional culmination."353 In the Netherlands, assisted dying procedures are performed by doctors who have known their patients for a long time. ${ }^{354}$ Conversely, in Oregon, from 1998 to 2008, the median duration of the patient-physician relationship prior to death was only 10 weeks. ${ }^{355}$ Moreover, prescribing physicians were present at their patients' deaths only $25 \%$ of the time. ${ }^{356}$ It seems paradoxical that a 'death with dignity' statute would neglect to even recommend that doctors be present with their patients when the drugs are ingested and death is pronounced. ${ }^{357}$ Even in the absence of complications, "it would still be a profound gesture of presence and commitment to remain with the patient to the very end."

note 72 .

348. OR. Rev. Stat. $§ 127.825$ (2009).

349. Ganzini et al., Prevalence of Depression, supra note 72.

350. Hendin \& Foley, supra note 333, at 1621. In patients who are unresponsive or whose physical and psychological symptoms overlap, depression can be difficult to diagnose. In general, however, diagnosing depression can be "relatively straightforward." Ganzini et al., Prevalence of Depression, supra note 72 . Chochinov proposes the simple yet effective screening method of asking patients whether they are depressed "most of the time." Chochinov, supra note 57 , at 86 . But while depression may be overlooked in some terminally ill patients, psychiatric diagnoses "provide too narrow a framework to contain the broad spectrum of end-of-life distress." Id.

351. Ganzini et al., Prevalence of Depression, supra note 72.

352. Ganzini et al., Attitudes of Oregon Psychiatrists Towards Physician-Assisted Suicide, 153 AM. J. PSYCHIATRY 1469, 1470 (1996).

353. Kimsma, supra note 47, at 2.

354. Id.

355. Oregon Department of Human Services, Public Health Division, 2008 Annual Report, Table 1, available at http://egov.oregon.gov/DHS/ph/pas/docs/yr11-tbl-1.pdf [hereinafter Oregon Department of Human Services, 2008 Annual Report].

356. Id.

357. Campbell, supra note 332 , at 42 .

358. Id. 
Perhaps the most far-reaching failing of ODDA is that, although it is now in its second decade of operation, it has generated disappointingly little information about the doctors and patients who participate in assisted dying. Pursuant to statute, OPHD does collect and publish demographic data annually; however, specifics regarding compliance with ODDA are not made available for public inspection. ${ }^{359}$ While this practice serves to protect doctor-patient confidentiality, it provides no mechanism for independent research. ${ }^{360}$ Moreover, data about patient concerns comes, not from the patients themselves, but from physicians who fill out a "government-issued standardized form" asking them to choose among pre-determined "generic categories."361

Much remains to be learned about patient motivation in hastened death-the nature of their illnesses, their responses to hospice and palliative care as well as to spiritual and mental health counseling, and why some patients make use of their prescriptions for lethal drugs while others do not. We need to know more about the quality of doctor-patient relationships in which assisted dying is discussed-how long and how well doctors know their patients, their areas of specialization, why they grant some requests and refuse others, and how they determine issues of competency. These and other areas of inquiry help not only to refine assisted dying law and policy, but also enhance our ability to understand and care for dying patients. By restricting access to such vital information, "OPHD is wasting the opportunity to study a natural experiment. ...,362

The complexities of human suffering call for flexible, creative, and even experimental, medical and legal strategies. It is somewhat dispiriting that Washington State's voters chose to enact a carbon copy of ODDA and that Montana may be contemplating legislation similar to that of Oregon. ${ }^{363}$ Future legislation should be based on detailed

359. OR. REV. STAT. $\S \S 127.865$ (2)-(3) (2009).

360. Hendin \& Foley, supra note 333, at 1614.

361. Campbell, supra note 332, at 39. Campbell expressed skepticism that the official reports filed by physicians under the ODDA accurately reflect

the existential experience of dying patients as they face their own mortality. The point of the ODDA was to empower, not silence, terminally ill patients, and transparency and accountability in a democratic society should allow us to hear patients in their own voices, not the rigid categories of political bureaucracy or physician interpretation.

Courtney Campbell, Correspondence: Debating "Death with Dignity," 23 NEW ATLANTIS 3, 6 (2009), available at $\mathrm{http}: / / \mathrm{www}$.thenewatlantis.com/docLib/20090203_TNA23Correspondence. pdf.

362. Hendin \& Foley, supra note 333 , at 1636.

363. Baxter v. Montana, No. ADV-2007-787, 2008 WL 6627324, at *23 (Mont. Dist. Ct. Dec. 5, 2008). 
exploration of end of life issues. This process would include testimony from, among others, doctors, patients, family members and palliative and hospice care professionals. Further, it is crucial that these laws and policies contain procedures for ongoing research and evaluation. Improving the care of dying patients demands openness, the sharing of ideas, and continual reassessment of our end of life measures and practices.

Discussions on the end of life arouse fear, discomfort, even outrage. But it is only by exposing, rather than suppressing controversy that we, ultimately, find the strength and wisdom to decide these matters for ourselves. As Sherwin Nuland explained:

In the United States and democratic countries in general, the importance of airing differing viewpoints rests not in the probability that a stable consensus will ever be reached but in the recognition that it will not. It is by studying the shades of opinion expressed in such discussions that we become aware of considerations in decision-making that may never have weighed in our soul-searching. Unlike the debates, which certainly belong in the public arena, the decisions themselves will always properly be made in the tiny, impenetrable sphere of personal conscience. And that is exactly as it should be. ${ }^{364}$

Whether the Supreme Court decides to revisit the issues in Washington v. Glucksberg ${ }^{365}$ is not as significant as what transpires at our country's regional and local levels. As Sylvia Law has noted, "While Supreme Court recognition of a constitutional right sounds like a grand affirmation of liberty, most often it is a mopping-up operation to bring the outliers into the consensus that has already been reached in the states." 366

\section{Promises, Promises: Hospice and Palliative Care}

Cicely Saunders, a pioneer in end of life care, believed firmly in the power of the "hospice and palliative care" movement. ${ }^{367}$ Thanks to her efforts, most health practitioners view hospice as "the most

364. NULAND, supra note 5, at 156.

365. 521 U.S. 702 (1997).

366. Sylvia Law, Choice in Dying: A Political and Constitutional Context, in QuiLl \& BATTIN, supra note 31, at 300, 305; see also K.K. DuVivier, Fast-Food Government and Physician-Assisted Death: The Role of Direct Democracy in Federalism, 86 OR. L. REV. 895, 898 (2007) (discussing the role of voter initiatives in "fostering innovation by allowing the states to serve as Brandeis laboratories.").

367. Cicely A. Saunders, A Hospice Perspective, in The CASE AGAINST Assisted SuICIDE: FOR THE RIGHT TO END-OF-LIFE CARE 281, 288 (Kathleen Foley \& Herbert Hendin eds., 2002). 
comprehensive form of end-of-life care available."368 Marcia Angell contends that, if high quality palliative care were universally accessible, "there would be few requests for assisted suicide.",369

It is somewhat disconcerting, therefore, to discover that hospice and palliative care are fallible. During ODDA's first decade, $86 \%$ of patients who officially hastened their deaths were enrolled in hospice. ${ }^{370}$ In $2008,98 \%$ were hospice patients. ${ }^{371}$ One possible explanation for these surprising numbers is that patients enroll in hospice "so late in the dying process" $\$ 72$ that they lack the time to benefit from the services offered. Still, in a study of terminally ill cancer patients, researchers found that palliative care, even of a high quality, did not obviate desire for hastened death. ${ }^{373}$ Another study found no "protective effect of hospice enrollment on patient mood at the end of life."

Hendin and Foley charge that, in Oregon, "referral to hospice cannot be regarded as a substantive palliative care intervention" 375 because treatment of pain for that state's terminally ill patients has worsened since ODDA went into effect. This assessment is at odds with that of others who believe that ODDA "served as a catalyst to improved endof-life care among Oregon practitioners." ${ }^{, 376}$ But while the vast majority of dying patients do benefit from hospice and palliative care, ${ }^{377}$ some suffering is so "inaccessible" 378 that it confounds all efforts to alleviate it. Pain, aggravated by emotional factors like anger, panic and fear, may resist the effects of opioid analgesics even in doses that are "sometimes astonishingly high.

368. Linda Ganzini, The Oregon Experience, in QuLL \& BATTIN, supra note 31, at 176.

369. Angell, The Quality of Mercy, in QUILL \& BATTIN, supra note 31, at 21.

370. Oregon Department of Human Services, 2008 Annual Report, supra note 355.

371. Id. 2008 Summary.

372. Bern-Klug, supra note 252, at 60.

373. Breitbart et al., supra note 64 , at 2911.

374. Rabkin et al., supra note 67 , at 84.

375. Hendin \& Foley, supra note 333, at 1619.

376. Campbell, supra note 332, at 36; see also Cassell, When Suffering Patients Seek Death, in QUILL \& BATTIN, supra note 31, at 87 ("One of the lessons of Oregon has been that offering aid in dying has improved palliative care and concern with end-of-life treatment."); Ganzini \& Back, supra note 338, at 113 ("either despite or even because of the Oregon law, there have been measurable improvements in end-of-life care since initial passage of the Act.").

377. Quill \& Cassell, Nonabandonment: A Central Obligation for Physicians, in QuILL \& BATTIN, supra note 31 , at 32. 79.

378. Cassell, When Suffering Patients Seek Death, in QuILL \& BATTIN, supra note 31, at

379. Id. at 82 . Terminal, or controlled, sedation, where a patient is medicated to the point of coma, is sometimes used in cases of intractable pain. It is generally given to patients "expected to die within hours to days," and its timing and appropriateness are determined by the physician, not the patient. Brigit R. Taylor \& Robert McCann, Controlled Sedation for Physical and Existential Suffering?, 8 J. PALliatIVE MED. 144, 146 (2005). Although terminal sedation, as well as voluntarily stopping eating and drinking, is "widely accepted by hospice and palliative 
Patients most likely to pursue a hastened death are prone to placing extraordinary value on independence and to poorly tolerate situations beyond their control. ${ }^{380}$ The dread of becoming dependent on others and the desire to master future events are lifelong traits deeply ingrained within the personality. ${ }^{381}$ For these patients, management of symptoms is often problematic and "[r]esponding with more palliative care is a double-edged sword" 382 because "more care fuels fears of more dependence on others." ${ }^{\text {,383 }}$

According to Dr. Eric Cassell, believing that suffering can almost always be relieved "displays an ignorance of what suffering is and how it comes about." 384 Promoting hospice and palliative care as the sole pathways to a good death, even in the face of their limitations, evinces "a professional pride that borders on hubris and rigidity." ${ }^{385}$ It also hinders the development of interventions that specifically address the existential concerns and fears of dependence that seem to evade existing remedies. ${ }^{386}$ What seems especially troublesome to opponents of assisted dying is the ideal of dignity "reduced to a notion of autonomy. ${ }^{, 387}$ Hendin and Foley regard the need to control the dying process as evidence of psychopathology. ${ }^{388}$ The wish to manage one's own dying is seen as aberrant and unseemly, as though patients should be expected to "get with the program and die right." ${ }^{389}$ It is hard to know what bothers the critics more: control in its own right or the confusion of autonomy and dignity that reveals the "impoverishment of our moral discourse" on assisted dying. ${ }^{390}$ But when we are at the point

care physicians," some doctors "continue to have moral objections and legal fears about these options." Dan W. Brock, Physician-Assisted Suicide as a Last Resort at the End of Life, in QuILl \& BATTIN, supra note 31, at 143. See also Anemona Hartcollis, Hard Choice for a Comfortable Death: Drug-Induced Sleep, N.Y. TIMES, Dec. 27, 2009.

380. Starks et al., supra note 91, at 223-24.

381. Ganzini \& Back, supra note 338, at 113; Pearlman et al., supra note 117, at 237.

382. Ganzini \& Back, supra note 338 , at 113.

383. Id. Back described one patient whose "top priority was to maintain a sense of control over his situation." Back, Doctor-Patient Communications, in QULL \& BATTIN, supra note 31, at 107. One morning, upon finding the mind-numbing effects of morphine intolerable, the patient stopped his pain medication, dismissed his hovering hospice care worker and shot himself. Id.

384. Cassell, When Suffering Patients Seek Death, in QuILL \& BATTIN, supra note 31, at 79.

385. Angell, The Quality of Mercy, in QuILL \& BATTIN, supra note 31, at 22.

386. Ganzini \& Back, supra note 338 , at 114.

387. Campbell, supra note 332 , at 45.

388. Hendin \& Foley, supra note 333 , at 1635-36.

389. Angell, The Quality of Mercy, in QuILL \& BATTIN, supra note 31, at 22; see also Ross Douthat, A More Perfect Death, N.Y. TIMES, Sept. 7, 2009 (charging those who seek assisted death as lacking in appreciation for the "limits of human agency, and the importance of humility in the face of death's mysteries.").

390. Campbell, supra note 332 , at 45 . 
of making our most private medical decisions, we have already absorbed whatever "moral discourse" has to offer and have moved on to a more individual analysis. We exercise control when we write an advance directive, refuse medical treatment, or voluntarily stop eating and drinking. Perhaps because these decisions are unaccompanied by the trumpeting of dignity, they attract less commentary. Thus, the choice of whether to "fight death or embrace $\mathrm{it}^{\text {"391 }}$ is a choice between technique and art, between trusting in the power of medicine to work miracles, or in one's personal and spiritual capacity to create a fitting end to life.

\section{The Art of Dying}

In Pittsford, N.Y., the elderly and dying members of the Sisters of St. Joseph convent rarely opt for invasive surgeries, high-tech diagnostic procedures or machines that sustain life; they decline all nonessential medications and die, not in hospitals, but within their community. ${ }^{392}$ Due to a lifetime of healthy habits, few if any suffer from diabetes (often caused by obesity), or chronic obstructive pulmonary disease (often brought on by smoking). The sisters' religious faith protects them from existential suffering and, rather than seeming afraid of death, they "know when to let it be." ${ }^{393}$ In the words of Dr. Robert C. McCann, geriatrician and the sisters' primary care physician, "they have better deaths than any I've ever seen."

Graceful aging and a peaceful death require no special setting, but are helped along by "a large social network, intellectual stimulation, continued engagement in life and spiritual beliefs" as well as health care that eschews aggressive interventions and relies on principles of hospice and palliative care. ${ }^{395}$ The funerals of St. Joseph's sisters are "more about the celebratory 'alleluia' than the glum 'De Profundis." 396 In this sense, they evoke the life-affirming, triumphant deaths of those eighteenth and nineteenth century Methodists described by Shai Lavi.

A good death can be a life's work, but most often the dying process is the cumulative result of genetics, choices and happenstance. If hastening death represents "a limited hope of mastery in the face of a hopeless condition," 398 it is also a means of conciliation between doctor

391. Lavi, How Dying Became a 'Life Crisis,' supra note 18, at 5.

392. Jane Gross, Sisters Face Death with Dignity and Reverence, N.Y. TIMES, July 9, 2009.

393. Id.

394. Id.

395. Id.

396. Id.

397. LAVI, THE MODERN ART Of DYING, supra note 11, at 39-40.

398. Lavi, How Dying Became a Life Crisis, supra note 18, at 64. 
and patient. Euthanasia and, by association, assisted suicide are "medicalized" forms of dying in that they require the assistance of the medical profession. ${ }^{399}$ But these practices also serve to highlight medicine's limitations. The assisted dying movement did more than improve hospice and palliative care. It forced us to reexamine our conceptions of a good death and how medicine helps us and hurts us in attaining it. The notion of control in dying is what validates the choice to forego expensive treatment of questionable value, and to die while still recognizable to ourselves and to others - not as alien beings in alien settings, "hooked to tubes, machines and chemotherapy bags." 400

The dilemma of art versus technique, of palliative versus curative care, is especially pertinent to our growing crisis in health care. In the struggle to contain expenses while expanding the reach of coverage, something has to give. Medicine has come to signify our fondest hope. Now we must ask it to account for itself.

\section{E. The Cost of Dying}

Apportioning health care's costs and resources is a rising and increasingly bitter challenge. The elderly, in particular, fear that they, more than anyone, will be called upon to sacrifice their health care benefits in the drive to achieve universal coverage. ${ }^{401}$ They may have some cause for concern. One-third of Medicare spending "goes to patients with chronic illnesses in their last two years of life," much of it to the elderly. ${ }^{402} \mathrm{~A}$ recent New York Times op-ed column recommended cutting the cost of "intensive-care medicine for dying, elderly people" and redirecting it to preventive care for younger patients. ${ }^{403}$ The author further warned that health care rationing was "imminent" and that, unless we curb the enormous cost of procedures like "by-pass surgery and titanium knee replacements" for the very old, we will be forced to "implement quick-and-dirty rules" based on arbitrary criteria, like age.

399. Id.

400. Anemona Hartcollis, At the End, Offering Not a Cure but Comfort, N.Y. TIMES, Aug. 20, 2009, at Al, available at http://www.nytimes.com/2009/08/20/health/20doctors.html? $r=1 \& s c p=1 \&$ sq $=$ not $\% 20 \mathrm{a} \% 20$ cure $\% 20 \mathrm{but} \% 20 \mathrm{a} \% 20$ comfort \&st $=$ cse [hereinafter Hartcollis, $\overline{A t}$ the End].

401. Kevin Sack, Where Elderly Back Obama, Health Bill Anxiety, N.Y. TIMES, Aug. 21, 2009, at A1, available at http://www.nytimes.com/2009/08/21/health/policy/21 housecall.html? scp $=1 \&$ sq $=$ elderly\%20health\%20care $\% 20$ anxiety \&st $=$ cse.

402. Hartcollis, At the End, supra note 400.

403. Richard Dooling, Health Care's Generation Gap, N.Y. Times, Aug. 17, 2009, at A1, available at http:/www.nytimes.com/2009/08/17/opinion/17dooling.html?scp=1\&sq=health\%2 0care\%20generation\%20gap\&st=cse.

404. Id. 
In voicing very real worries about health care rationing, it is not entirely logical to single out the elderly. By-pass surgery for an otherwise healthy and vibrant ninety year-old reduces Medicare costs by eliminating "repeated hospitalizations for heart failure." ${ }^{, 405}$ In a younger patient suffering from cancer, congestive heart failure or dementia, aggressive, life-prolonging procedures do not necessarily improve quality of life. ${ }^{406}$ Even more than age, socio-economic status is a "powerful predictor of health and well-being." 407 The highest rates of morbidity and mortality from most major types of cancer occur among poor and minority populations. ${ }^{408}$ In blacks, "[43\%] of all deaths occur before age [65] compared to [22\%] in whites. ${ }^{, 409}$ These ready-made inequities further intensify fears about health care rationing.

A measure of the blame for runaway health care spending falls on government and private insurance payment systems. Physicians are often rewarded for ordering more tests and procedures because, "[T]he more tubes you put in, the more you get paid." ${ }^{.410}$ This bountiful flow of cash seems to dry up, however, when less heroic measures are called for. In the case of an 88 year-old woman with a weak heart and a likelihood of cancer, "[M]edicare would pay hundreds of thousands of dollars for endless hospital procedures and tests but would not pay $\$ 18$ an hour for a non-hospice caregiver to come into [the patient's] home and help her through her final days."

A good many patients are incapable of saying no to costly and futile medical treatment. Dr. Joseph Sacco writes of the "thousands of New Yorkers," incurably ill, mentally incompetent, and lacking in signed health care proxies or surrogates, "for whom the prolongation of life [is] the only legally sanctioned course of treatment." ${ }^{.412}$ Green, a fifty-nine year-old patient with AIDS-related dementia and fever was confined to bed and a ventilator. He was a "valuable commodity" in terms of hospital and nursing home Medicare reimbursement. ${ }^{413}$ His monetary

405. Anemona Hartcollis, Rise Seen in Medical Efforts to Treat the Very Old, N.Y. TDMES, July 18,2008 , at $\mathrm{A} 1$.

406. Id.

407. Williams, supra note 34 , at 28 .

408. Id. at 33 .

409. Id. at 32 . Williams provides a moving account of suffering unique to dying "before one's time." Id.

410. Reed Abeison, Weighing Medical Costs of End-of-Life Care, N.Y. TIMES, Dec. 23, 2009, available at http://www.nytimes.com/2009/12/23/health/23ucla.html?hp (quoting Dr. Patrick T. Dowling, chairman of the department of family medicine at U.C.L.A.).

411. Timothy Egan, The Way We Die Now, N.Y. Times, Sept. 23, 2009, available at http://opinionator.blogs.nytimes.com/2009/09/23/the-way-we-die-now/?emc=eta1.

412. Joseph Sacco, Incapacitated, Alone and Treated to Death, N.Y. TimES, Oct. 7, 2008, at D5.

413. Id. 
value as a patient also influenced his care. ${ }^{414}$ Despite the poorest of prognoses, Green's perpetual status on life support subjected him to pneumonias, infections, and other complications, all of which required transfers between hospital and nursing home, and all of which resulted in reimbursement to the various providers for these procedures. ${ }^{415} \mathrm{His}$ wishes unknown, Green was "treated to death"416 because his doctors thought it was their legal and ethical obligation to do so. "Modern American medicine," said Dr. Sacco, "owed him a better way." did our system of law and ethics. ${ }^{418}$

In the context of scarcity in health resources, it seems reasonable to place a lower priority on patients closer to death. But even in war, accidents and disasters, standards of triage are subject to a lack of consensus. ${ }^{419}$ How to achieve "the greatest good for the greatest number of people" raises a series of difficult questions: "Is it the number of lives saved? Years of life saved? Best 'quality' years of life saved? Or something else?" ${ }^{420}$ In the aftermath of Hurricane Katrina, a nurse at New Orleans' Memorial Hospital defended her actions in injecting an elderly, unconscious woman with morphine and sedatives, hastening her death: "But even if it had been euthanasia," she said, "It's not something we don't really do every day-it just goes under a different name. ${ }^{42 P}$ In order to acquire legitimacy, health care allocations systems must be perceived as fair and just by the populations they serve. This can only be achieved if policies are "publicly understandable, accessible and subject to public discussion and revision. $\$ 422$

414. Id.

415. Id.

416. Id.

417. Id.

418. Sacco asserted that, for mentally incapacitated patients who are critically or terminally ill, who lack surrogates and who have given no evidence of their wishes, withholding treatment is "a practice that is neither regulated nor publicly recognized." Id. In New York, even where surrogates are available, withholding or withdrawing treatment is prohibited without a signed health care proxy or clear and convincing evidence of a patient's wishes. See id. In some states, surrogates are permitted to make decisions about life support, with or without knowledge of the patient's wishes; in others, where surrogates are lacking, it is doctors who decide whether or not to continue life support. Id. In one study of a metropolitan hospital intensive care unit, $16 \%$ of patients admitted during a specific time period lacked surrogates and decision-making capacity. Douglas B. White et al., Decisions to Limit Life-Sustaining Treatment for Critically Ill Patients Who Lack Decision-Making Capacity and Surrogate Decision-Makers, 43 CRITICAL CARE MED. 2053-59 (2006). Physicians made decisions to withhold or withdraw treatment for $37 \%$ of these patients, and sought guidance from the courts or the hospital ethics committee in a small minority (11\%) of these cases. See id. at 2053-59.

419. Sheri Fink, The Deadly Choices at Memorial, N.Y. TIMEs MAG., Aug. 30, 2009, § 6 (magazine), at 34.

420. Id.

421. Id. at 42 .

422. Govind Persad et al., Principles for Allocation of Scarce Medical Interventions, 373 


\section{F. Planning for Death}

Only about one-third of Americans have advance-care directives specifying their wishes for treatment at the end of life. ${ }^{423}$ In the absence of directives, families and health providers of terminally ill, incapacitated patients are stricken with uncertainty as life-prolonging procedures mount up, at considerable expense. Measures such as California's Right to Know End-of-Life Options Act $^{424}$ aim to address these untimely information deficits. Under the Act, health care providers must, at the request of terminally ill patients, provide comprehensive information and counseling on end-of-life options. ${ }^{425}$ The range of services to be discussed is quite inclusive, covering hospice and palliative care, advance directives, refusal or withdrawal of life-sustaining treatment, right to pursue disease-targeted treatment and to receive prognoses with or without such treatment. ${ }^{426}$ The focus on terminal illness (a term undefined in the statute), however, ignores the difficulty doctors sometimes face in quantifying the amount of time remaining to a particular patient. ${ }^{427}$ Further, the statute makes no provision for patients with "seriously compromised and declining health," or those who are chronically ill, frail and "at high risk of dying at a time uncertain." ${ }^{, 428}$ This omission leaves a large number of dying patients with no statutory recourse for obtaining crucial end of life information.

Advance directives, long touted as a means to achieve patient selfdetermination, may be underutilized because they are conceptually defective. Rosenfeld et al. contend that eliciting patient preference for specific lifesaving procedures, like CPR, is misguided. ${ }^{429}$ Rather, they suggest speaking about interventions in terms of their outcomes, evaluating their desirability as to whether they can "return a patient to his or her most valued activities. ${ }^{, 430}$ Further, in treatment decisions

LANCET 423, 429 (2009). The authors propose distributing scarce health care resources according to a method they term "the complete lives system." Id at 423 . Based on the belief that "enabling more people to live complete lives is better than enabling fewer," the system favors younger people with better prognoses. Id. at 428-29.

423. Charles Lane, Undue Influence, WASH. PosT, Aug. 8, 2009, at A13.

424. Cal. Health \& SAfETy CODE $\S 442$ (Deering 2009).

425. Id. $\S 442.5$.

426. Id.

427. Id. $\S 442$.

428. Bern-Klug, supra note 252, at 61.

429. Kenneth E. Rosenfeld et al., End-of-life Decision-Making, 15 J. GEN. INTERN. MED. 620 (2000), available at http://www.pubmedcentral.nih.gov/articlerender.fcgi?artid=1495587.

430. Id. 
where advanced age is a factor, patients should be encouraged to "place more emphasis on maintaining function than on longevity per se."

McCue has suggested that, in cases of naturally dying, very elderly patients, we push "medicalization a step farther" and "make dying a diagnosis." 432 Recognizing these patients' conditions as incurable and chronic minimizes the risk of harmful, aggressive interventions and allows caregivers to concentrate on spiritual needs and symptom relief. $^{433}$ Bern-Klug proposes revamping our notion of mortality and "replacing our dichotomous conceptualization of living and dying with that of a continuum." ${ }^{\text {"434 }}$ The prevalence of chronic health conditions lacking in predictable dying trajectories require that we "expect ambiguity and plan for it.

Two earlier incarnations of California's Right to Know End-of-Life Options Act contained provisions similar to Oregon's Death with Dignity Act, allowing terminally ill patients to hasten their deaths with medical authorization. ${ }^{436}$ Both measures were defeated in 2006 and 2007. The current, more modest measure drew the same opposition from conservative religious groups as the previous versions. ${ }^{437}$ The fear of undue influence could be why the Act requires that patients, not doctors, must initiate end-of-life dialogues. In view of Americans' dismal showing in the preparation of advance directives, however, it seems obvious that patients cannot be relied upon to anticipate critical end of life issues. Moreover, patients hesitate to broach the subject of impending death with their physicians, many of whom would rather not talk about it. Often, through a combination of denial, fear and lack of clarity in patient-doctor discussions, the seriously ill "do not realize the extent to which they are vulnerable to death until death is clearly upon them." 438 By then, patients may have missed the opportunity to benefit from their end of life options.

\section{G. Roles and Responsibilities}

The role of palliative care has grown from symptom management to encompassing the resolution of dying's ambiguities. Palliative care specialists believe in the "frank acknowledgment of the inevitability of

431. Id.

432. McCue, supra note 4, at 1041.

433. Id.

434. Bern-Klug, supra note 252 , at 61 .

435. Id.

436. Frank D. Russo, California Assembly Approves Right to Know End-of-Life Options Act, California Progress Report, available at http://www.californiaprogressreport.com/2008/05/ california_asse_28.html.

437. $\bar{I} d$.

438. Bern-Klug, supra note 252 , at 61 . 
death." 439 Unlike most physicians, they have "made death their life's work" and excel at the delivery of bad news. ${ }^{440}$ While their job is not to hasten death or limit patient choice, they do encourage patients to think carefully about the treatments that they might and might not want.

Proponents of assisted death stop short at recommending that hospice and palliative care programs publicly endorse physician aid in dying. ${ }^{441}$ Doing so would frighten patients "already fearful and vulnerable," and might prevent them from openly discussing their distress. ${ }^{442}$ Still, it would be interesting to know how often palliative and hospice care professionals are asked about assisted dying and how they respond. Having observed that aid in dying is a subject "often blocked by physicians," Anthony L. Back wondered whether doctors "underestimate the degree to which patients wish to talk about assisted suicide." ${ }^{443}$ Starks and her colleagues related that, in the United States, $18-24 \%$ of primary care physicians and $46-57 \%$ of oncologists reported "having been asked for their assistance in a patient's hastened death and about one-quarter of them complied." 444 In Britain, 3,000 deaths per year occur due to voluntary and involuntary euthanasia "outside any legal framework." ${ }^{445}$ In this light, statutes like ODDA are as much about regulating an existing practice as they are about defining an entitlement. The question is whether we can ever satisfactorily formulate rules for the deeply private and painful decision to hasten death, or whether each case creates its unique personal and moral standard. ${ }^{446}$

Even in a more tolerant atmosphere, patients asking about hastened death are knocking at a door that will never widely open. In a letter to the British Medical Journal, one angry radiologist, strongly opposed to doctors "involved with killing people," proposed erecting "thanatoria" with volunteers trained as "despatchers." extremists at both ends of the assisted dying debate would have to admit that "[t] here is no right way to die." 448 Some find suffering ennobling while others find it dehumanizing. Despite the injunction to do no harm,

439. Hartcollis, At the End, supra note 400.

440. Id.

441. Cassell, When Suffering Patients Seek Death, in QuLL \& BATTI, supra note 31, at 87.

442. Stephen Hutchinson, Legalising Euthanasia Needs Careful Thought, INVERNESS CoURIER, Dec. 23, 2008, available at http://www.unverness-courier.co.uk/news/fullstory.php/ aid/8305/Legalising_euthanasia_needs_careful_thought.html.

443. Back, Doctor-Patient Communications, in QULl \& BATTN, supra note 31, at 112.

444. Starks et al., supra note 260 , at 126.

445. Charlemagne, The Great Euthanasia Debate, ECONOMIST, Apr. 4, 2009, at 56.

446. See id.

447. Bob Bury, Letter, 324 BRIT. MED. J. 848 (2002).

448. Angell, The Quality of Mercy, in QuILL \& BATTIN, supra note 31, at 23. 
"indelibly stamped into the doctor's whole being,"449 we must accept the fact that, for a good many patients, death is not a harm. ${ }^{450}$

It is dying that frightens us. That many patients who procure lethal prescriptions are comforted, reassured and relieved, whether or not they ultimately use the drugs, is revelatory. ${ }^{451}$ We must find ways to interpret and make use of this finding in order to calm the fears of the seriously ill. Unless we are willing to allow scare tactics about undue influence to take the place of reason, it is imperative that we permit doctors to take a more proactive role in end of life discussions. Patients do not know how to ask, and their reticence should not condemn them to a bad death.

In a perfect world, palliative medicine will have become so advanced as to address all forms of suffering. Even so, there will always be a small minority of patients whose last wish is to depart this life strictly on their own terms. What they choose to do should be of little consequence to us as individuals. ${ }^{452}$ Taking responsibility, in whatever form, for our own end of life is what is at issue. When we peer too closely and critically at the desires and motivations of others, we tend to forget that dying is not something that happens only to other people. To paraphrase Walt Kelly's eminent philosopher Pogo, we have met the dying, and they are us.

449. Cassell, When Suffering Patients Seek Death, in QUILL \& BATTIN, supra note 31, at 77.

450. Taylor \& McCann, supra note 379, at 145.

451. Ganzini et al., Prevalence of Depression, supra note 72.

452. See RONALD DWORKIN, LIFE's DOMINION 213 (1993).

Whether it is in someone's best interests that his life end in one way rather than another depends on so much else that is special about him-about the shape and character of his life and his own sense of his integrity and critical interests-that no uniform collective decision can possibly hope to serve everyone even decently.

Id.

453. Walt Kelly, Pogo: We Have Met the ENEMy and He is Us (1972). Kelly was himself rephrasing Oliver Hazard Perry's "We have met the enemy, and they are ours." 
